\title{
Distribution of benthic diatoms in Korean rivers and streams in relation to environmental variables
}

\author{
Soon-Jin Hwang ${ }^{1 *}$, Nan-Young Kim ${ }^{1}$, Sung Ae Yoon ${ }^{1}$, Baik-Ho Kim ${ }^{1}$, Myung Hwan Park ${ }^{1}$, \\ Kyung-A You ${ }^{1}$, Hak Young Lee ${ }^{2}$, Han Soon Kim ${ }^{3}$, Yong Jae Kim ${ }^{4}$, Jungho Lee ${ }^{5}$, Ok Min Lee ${ }^{6}$, \\ Jae Ki Shin ${ }^{7}$, Eun Joo Lee ${ }^{8}$, Sook Lye Jeon ${ }^{9}$ and Huyn Soo Joo ${ }^{10}$ \\ ${ }^{1}$ Department of Environmental Science, Konkuk University, Seoul 143-701, Republic of Korea \\ 2 Department of Biological Science, Chonnam National University, Gwangju 500-757, Republic of Korea \\ 3 Department of Biology, Kyungpoouk National University, Daegu 702-701, Republic of Korea \\ 4 Department of Biology, Daejin University, Phochon 487-711, Republic of Korea \\ 5 Department of Biological Education, Daegu University, Gyeongsan 712-714, Republic of Korea \\ 6 Department of Biology, Kyonggi University, Suwon 443-760, Republic of Korea \\ 7 K-Water Research Institute, Korea Water Resources Cooperation, Daejon 305-730, Republic of Korea \\ 8 Institute of Korean Alagetech, Gangneung 210-793, Republic of Korea \\ 9 R\&D Center, KORBI Co. Ltd, Anyang 431-755, Republic of Korea \\ 10 Department of Parasitology, College of Medicine, Seonam University, Namwon 590-711, Republic of Korea
}

Received 30 August 2010; Accepted 5 February 2011

\begin{abstract}
The diatoms are an ecologically important group of algae that have been extensively studied by ecologists and taxonomists. However, the large-scale patterns of diatom distribution and the factors underlying this distribution are largely unknown. The aims of this study were to identify the large-scale spatial patterns of benthic diatom assemblages in Korean streams and rivers, and to assess the importance of numerous environmental factors on diatom distribution. We classified 720 study sites based on diatom flora. Benthic diatoms, water chemistry, altitude, and riparian land cover and use were characterized by multivariate analyses, Monte Carlo permutation tests, and indicator species analysis. In total, we identified 531 diatom taxa. Diatom assemblages were mostly dominated by species of the genera Achnanthes, Navicula, Nitzschia, Cocconeis, Fragilaria (Synedra included), Cymbella, Gomphonema, and Melosira. Cluster analysis partitioned all 720 sites into eight groups based on diatom species composition. Canonical correspondence analysis indicated that altitude, land cover and use, current velocity, electrical conductivity, and nutrient levels explained a significant amount of the variation in the composition of assemblages of benthic diatoms. At the national scale, a downstream ecological gradient was apparent, from fast-flowing, mostly oligotrophic highland streams to slow-flowing, mostly eutrophic lowland rivers. Our data suggest that spatial factors explain some of the variation in diatom distribution. The present investigation of the spatial patterns of benthic diatoms, the ecological determinants of diatom occurrence, and the identification of diatom indicator species contributes to development of a program for assessing the biological integrity of lotic ecosystems in Korea.
\end{abstract}

Key words: Benthic diatoms / spatial patterns / multivariate analyses / ecological gradient / bioassessment

\section{Introduction}

Diatoms are the most diverse group of algae in rivers and streams (Leland and Porter, 2000). They constitute a large proportion of the total algal biomass in many environments, and are a high-quality food source for higher trophic levels in aquatic food webs (Stevenson et al., 1996).

\footnotetext{
*Corresponding author: sjhwang@konkuk.ac. kr
}

Many studies have reported a wide distribution of benthic diatoms (Watanabe et al., 1990; Choi et al., 1995; Leland and Porter, 2000; Weckström and Korhola, 2001; Potapova and Charles, 2002; Soininen et al., 2004; Leira and Sabater, 2005; Bona et al., 2007; Wu et al., 2009) and their tolerance to gradients of diverse environmental variables (Watanabe et al., 1990; Potapova and Charles, 2002). However, other studies have reported that some species only occur in particular geographical locations, water bodies, or micro-habitats (Kociolek and Spaulding, 
Table 1. Characteristics of the five studied river watersheds in Korea, and the number of rivers and streams and sites in each watershed. Data from "Water Management Information System" (WAMIS, http://www.wamis.go.kr) and "A list of rivers in Korea" (The Ministry of Land, Transport and Maritime Affairs of Korea, 2008).

\begin{tabular}{lccccrrr}
\hline Watershed & $\begin{array}{c}\text { Length of main } \\
\text { stream }(\mathrm{km})\end{array}$ & $\begin{array}{c}\text { Number of } \\
\text { tributaries }\end{array}$ & $\begin{array}{c}\text { Total stream } \\
\text { length }(\mathrm{km})\end{array}$ & $\begin{array}{c}\text { Watershed } \\
\text { area }\left(\mathrm{km}^{2}\right)\end{array}$ & $\begin{array}{c}\text { Human } \\
\text { population }\end{array}$ & $\begin{array}{c}\text { Number of } \\
\text { study streams }\end{array}$ & $\begin{array}{c}\text { Number of } \\
\text { study sites }\end{array}$ \\
\hline Han River & 560.0 & 912 & 8567.7 & 41957.0 & 23404251 & 170 & 320 \\
Nakdong River & 470.0 & 1185 & 9637.6 & 31785.0 & 14431507 & 75 & 130 \\
Geum River & 393.1 & 876 & 6134.9 & 17537.0 & 5721207 & 76 & 130 \\
Youngsan River & 117.7 & 576 & 3540.4 & 12833.4 & 3800240 & 47 & 76 \\
Seomjin River & 211.9 & 283 & 1928.8 & 4914.3 & 319614 & 20 & 64 \\
& & & & & & & 388 \\
Total & 1752.7 & 3832 & 29809.4 & 109026.7 & 47676819 & 720 \\
\hline
\end{tabular}

2000). Rivers and streams are complex ecosystems in which many environmental factors vary on spatial and/ or temporal scales. These factors include climate, geomorphology, and land use in the watershed as well as the physical, chemical, and biological properties of rivers and streams. Previous studies have shown that the distribution of diatoms depends on environmental factors (Pan et al., 2006) such as climate and eco-hydrological regimes (Weckström and Korhola, 2001), geomorphic characteristics and land use (Leland and Porter, 2000), nutrient concentrations (Biggs and Smith, 2002), ionic composition (Potapova and Charles, 2003), and herbivory (Anderson et al., 1999).

Diatoms are sensitive to physical, chemical, and biological changes in lotic ecosystems, and their very short generation times allow them to respond rapidly to these changes. The sensitivity of diatom physiology to habitat conditions manifests as a great ecological variability in biomass and species composition (Stevenson et al., 1996). This variability, which can lead to uncertainties in ecological status assessment (Kelly et al., 2009), is due to complex interactions among ecological variables that can affect diatom physiology and community composition (Stevenson, 1997). Despite these uncertainties, studies of diatom distribution provide an effective tool for assessing the ecological integrity of various lotic ecosystems (Kelly and Whitton, 1995; Whitton and Rott, 1996; Kelly, 2002).

Since Skvortzow first reported the presence of freshwater diatoms in Korea in 1929 (Skvortzow, 1929), there has been substantial development of diatom taxonomy. A total of 1457 species of diatoms have been identified in freshwater and marine ecosystems in Korea, among which 724 species have been reported in freshwaters (Choi et al., 1995). However, there is limited information on diatom distribution and biogeography in Korean lotic ecosystems and on the use of benthic diatom assemblages for bioassessment (Lee and Chung, 1992; Hwang et al., 2006; Kim, 2007). The present study was conducted as part of a Korean government-led nationwide biological survey of rivers and streams (MOE/NIER, 2008) that aims to develop national biological criteria under the National Aquatic Ecological Monitoring Program (NAEMP). The purpose of the NAEMP is to establish a national biomonitoring network to assess the biological and ecological status of stream and river ecosystems, and to develop a strategy for the restoration and management of disturbed systems. The NAEMP also aims to assess macroinvertebrates, fish, and riparian habitats.

We performed a synoptic study of the spatial distribution of benthic diatoms in Korea in relation to numerous environmental variables. Our specific objectives were to (i) characterize the geographic distribution of benthic diatom assemblages, (ii) identify the major environmental factors that affect diatom distribution, and (iii) identify diatom indicator species and the major factors that affect their presence.

\section{Materials and methods}

\section{Study sites}

Samples were collected at 720 study sites from 388 streams and rivers in the five major river systems of Korea during September and October 2009 as a part of NAEMP (Table 1, and see also Fig. 3). The Han River Watershed (HRW), located in the central region of the Korean peninsula, and the Nakdong River Watershed (NRW), in the southeast of the peninsula, include most of the study area and of the human population of Korea. The Han River runs through Seoul, the biggest city in Korea, and the Nakdong River runs through Busan and Daegu, the second and third biggest cities, respectively. The Guem River Watershed (GRW) and the Youngsan River Watershed (YRW) are in the western part of the country, and the Seomjin River Watershed (SRW) is between the NRW and the YRW (Fig. 3). The largest number of study sites were in the HRW (320) followed by the watersheds of the NR (130), the GR (130), the YR (76), and the SR (64) (Table 1). All sampling and field measurements were conducted according to the guidelines of the "National surveys for stream ecosystem health" (MOE/NIER, 2008).

\section{Analysis of environmental data}

Physico-chemical and hydrological factors were measured at all 720 sampling sites. These included measurements of water temperature, dissolved oxygen concentration, electrical conductivity (EC), and $\mathrm{pH}$, which were measured in situ with a multi-probe meter (YSI 6920, YSI Inc., USA). Stream and river water was sampled for analysis of water quality variables. Three water samples 
( $2 \mathrm{~L}$ each) were collected in sterile plastic bottles at each site and transported to the laboratory on ice. Biological oxygen demand (BOD), total nitrogen (TN), $\mathrm{NO}_{3}-\mathrm{N}$, $\mathrm{NH}_{3}-\mathrm{N}, \mathrm{PO}_{4}-\mathrm{P}$, and total phosphorus (TP) were determined by standard methods (APHA, 2001). The current velocity was measured at each sampling site using a current meter (Model 2100, Swoffer Inc., USA). In addition, reach-scale riparian conditions were assessed in the area adjacent to each study site according to US EPA guidelines (Barbour et al., 1999) for qualitative habitat analysis, and were recorded as a percentage of land use and land cover type (e.g., forest, agriculture, urban).

\section{Benthic diatom sampling and identification}

Most field investigations were conducted in wadeable sites of the selected streams and rivers. To collect benthic diatoms, pebbles $(\sim 10 \mathrm{~cm}$ diameter $)$ were collected at three to five regions in the riffle zone along a transect at each study site. For deeper sites, in which riffles were not present, substrates were collected at the edge of the target transect. A known surface area of the sampled substrate was scrubbed with a toothbrush and rinsed with distilled water on site to collect surface-attached diatoms. The collected material was placed in a plastic bottle and transported to the laboratory on ice and analyzed within one week. Prior to analysis, all diatom samples from each study transect were combined, and the composite samples were subsampled for subsequent determination of abundance and assemblage structure.

Diatom specimens for microscopy were mounted in Naphrax ${ }^{\circledR}$ following the methods of Barbour et al. (1999). Diatom counts and identification were performed at $\times 1000$ magnification using a light microscope (Zeiss, Axioskop 2, Germany), and photographs were taken for subsequent use (Roper Scientific Photometrics, COOL SNAP ${ }^{\mathrm{TM}}$ ). For assessment of diatom density $\left(\right.$ cells.cm ${ }^{-2}$ ), at least 500 diatom cells were counted in each sample.

Diatoms were identified primarily according to Krammer and Lange-Bertalot (1986, 1988, 1991a, 1991b) and Watanabe (2005), although other relevant monographs, illustrations, and articles were also consulted. Identification and counting were performed using common taxonomic criteria based on morphotypes. We included some unidentified specimens in well-established taxa, based on comparisons of morphology and other relevant information, to enable combination of all counts into a single dataset.

\section{Data analysis}

Two different multivariate analyses, cluster analysis and canonical correspondence analysis (CCA), were used to characterize relationships between diatoms and environmental variables. Rare taxa, defined as those occurring at $<5 \%$ of all total sites, were excluded in the multivariate analysis. Prior to this analysis, benthic diatom density data were log-transformed to reduce variation; a value of 1 was added to all data points to avoid the problem of $\log 0$ being undefined. The data were rescaled in the range $0-1$ based on the min-max transformation, which gave the same level of importance to all species in the analysis.

Cluster analysis was conducted to classify the spatial distribution of benthic diatom communities using the flexible beta method $(\beta=-0.25)$ with the Sorenson distance measure (McCune and Grace, 2002). Samples were classified into clusters based on similarities of community composition. A multi-response permutation procedure (MRPP; Mielke et al., 1976), a non-parametric method for testing the hypothesis of "no difference between two or more groups of entities", was used to evaluate the statistical significance of the clusters. Cluster analysis and the MRPP were conducted using PC-Ord (McCune and Mefford, 1999). Differences in environmental variables among clusters were evaluated using the Kruskal-Wallis test and Dunn's non-parametric multiple comparisons test with STATISTICA software (StatSoft, 2004).

Indicator species analysis (IndVal; Dufrene and Legendre, 1997) was used to identify potential indicator species in each cluster defined in the cluster analysis. The indicator value for each species in a group is the product of its relative abundance and relative frequency $(\times 100)$, and ranges from 0 (no indication) to 100 (perfect indication) (Petersen and Keister, 2003). Thus, a perfect indicator of a group should be consistently and uniquely associated with that group, and should never occur in other groups (McCune and Grace, 2002). In this study, a species in a cluster that had an IndVal more than five times greater than in any other cluster was defined as good indicator species for that cluster (Keister and Peterson, 2003). A Monte Carlo method was used to determine the significance of IndVals.

CCA was also used to evaluate the relationships between the distribution of diatom assemblage types and environmental variables by use of a previously described procedure (ter Braak, 1987). The significance of each CCA axis was tested using unrestricted Monte Carlo permutations. To assist interpretation of changes in community profile between dimension scores, Pearson's correlation coefficients between scores and environmental variables were calculated. Cluster analysis, IndVal, and CCA were conducted using PC-Ord software (McCune and Mefford, 1999).

\section{Results}

\section{Environmental factors}

Table 2 shows a summary of selected variables pooled from studied rivers and streams of each major river watershed, including altitude, riparian land cover and type of use, current velocity, and water chemistry. The rivers we studied varied widely in water chemistry, physiography, and land cover and type of use. On average, rivers and streams of the HRW had the highest altitude 


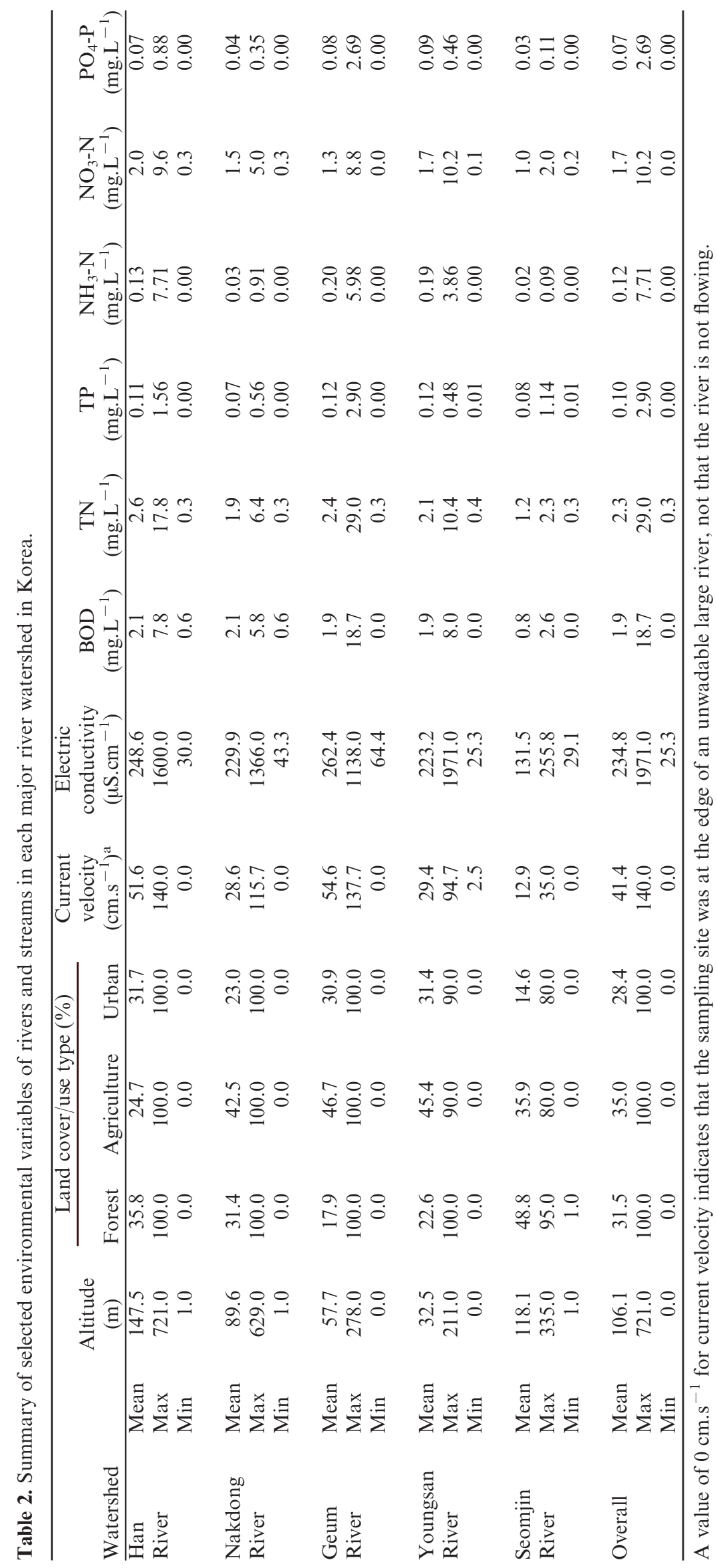




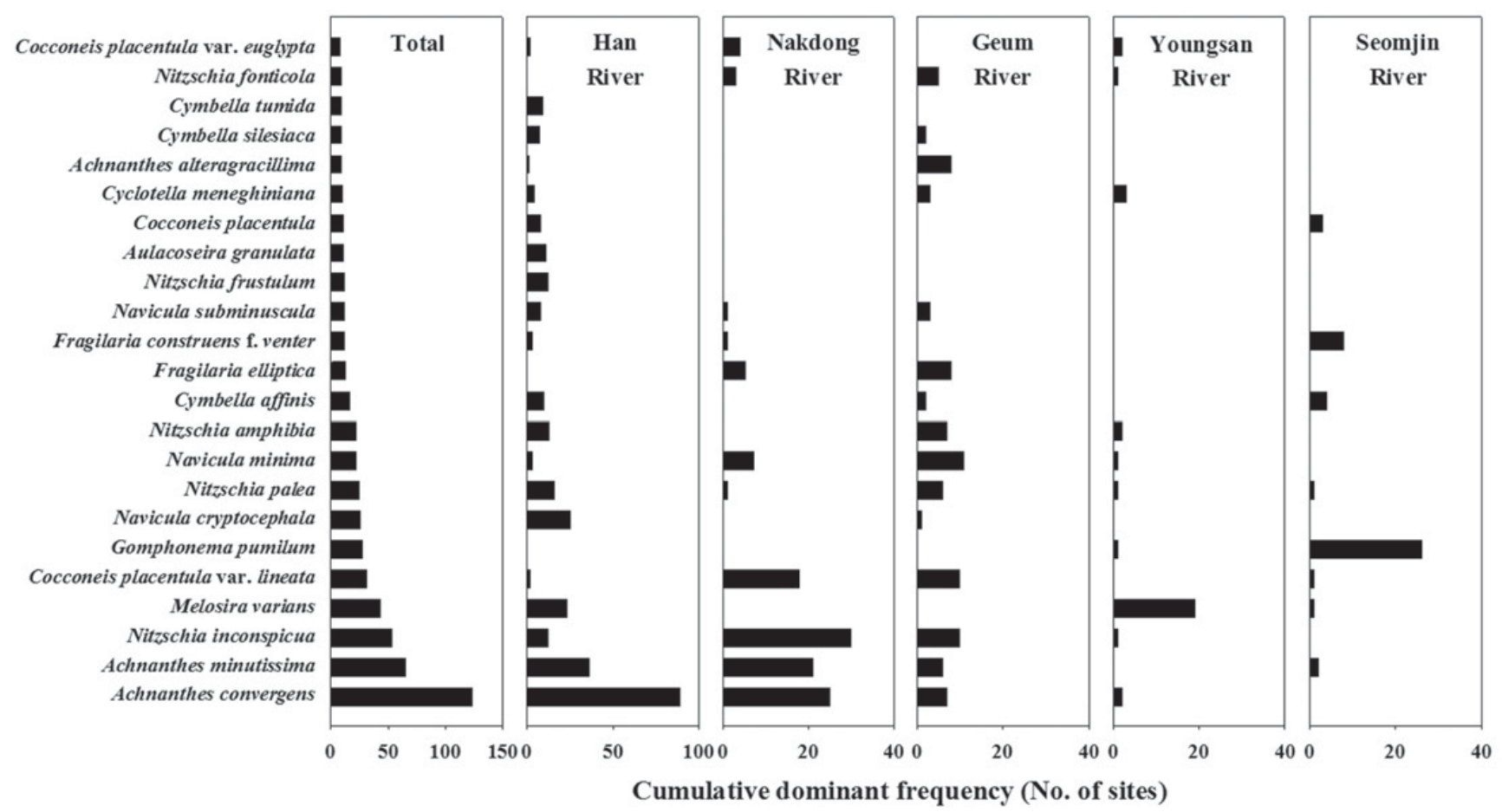

Fig. 1. Diatom distribution in the five major river systems in Korea. The abscissa indicates the percentage of sites in which each diatom species occurred, and a different scale was used for each river system.

(mean $147.5 \mathrm{~m}$ ) and the highest proportion of forest land cover $(35.8 \%)$; the altitude and proportion of forest cover of rivers and streams in the SRW were also significant. The rivers and streams in the NRW, the GRW, and the YRW were at low altitude and had relatively high proportions of agricultural land. Among all 720 study sites, the current velocity ranged from 0 to $140.0 \mathrm{~cm} . \mathrm{s}^{-1}$; among the five major river watersheds, the average current velocity ranged from 12.9 to $54.6 \mathrm{~cm} . \mathrm{s}^{-1}$. Relatively fast flow was recorded at the sites of the HRW and GRW, and slow flow at the SRW. The average levels of electric conductivity, BOD, and nutrients ( $\mathrm{N}$ and $\mathrm{P}$ ) were low at the SRW sites, indicating rather homogeneous water chemistry relative to the other river systems.

\section{Community composition}

A total of 531 diatom taxa were recorded from the 720 study sites. The YRW had the greatest number of species (340 taxa), followed by the HRW (287 taxa), GRW (259 taxa), NRW (179 taxa), and SRW (161 taxa) (see the taxonomic list in the Appendix). There were 81 taxa that occurred at more than $5 \%$ of all sites, and these taxa were used for subsequent site classification analysis.

The dominant taxa varied among the different river systems. Achnanthes convergens H. Kobayasi was the most common species and was present at $17 \%$ of all sites; this species was the most dominant species in the HRW, and the second most dominant species in the NRW (Fig. 1). Interestingly, $A$. convergens was rare in the Youngsan River System (YRS) and Seomjin River System (SRS); instead, Melosira varians C. Agardh was predominant in the YRW and Gomphonema pumilum (Grunow) Reichardt \& Lange-Bertalot was predominant in the SRW. Achnanthes minutissima Kützing was the second most common species nationwide (observed at $9.0 \%$ of all sites), and was predominant in the HRW and the NRW. Nizschia inconspicua Grunow was present at $7.4 \%$ of all sites, and was particularly dominant in the NRW. $M$. varians occurred at $6.0 \%$ of all sites, and was the most dominant species in the YRW. Cocconeis placentula var. lineata (Ehrenberg) Van Heurck occurred at $4.3 \%$ of all sites, and was predominant in the NRW and the GRW. These six benthic diatom species accounted for $48 \%$ of the diatoms in all 720 study sites.

\section{Diatom-based site classification}

Based on similarities of diatom community composition, cluster analysis (Sorensen's distance measure) classified all 720 study sites into four clusters or eight clusters (Figs. 2 and 3). Group 1 (318 sites) was divided into four subgroups (Group 1a, 89 sites; Group 1b, 45 sites; Group 1c, 67 sites; Group 1d, 117 sites); Group 2 (153 sites) was divided into two subgroups (Group 2a, 86 sites; Group 2b, 67 sites); Group 3 (57 sites) and Group 4 (192 sites) were not subdivided (Fig. 2). The MRPP indicated statistically significant differences among the four clusters and among the eight clusters $(A=0.150, P<0.001)$.

Differences of clusters were associated with differences in environmental conditions and geographical location of sampling sites, especially with hydrological systems. 


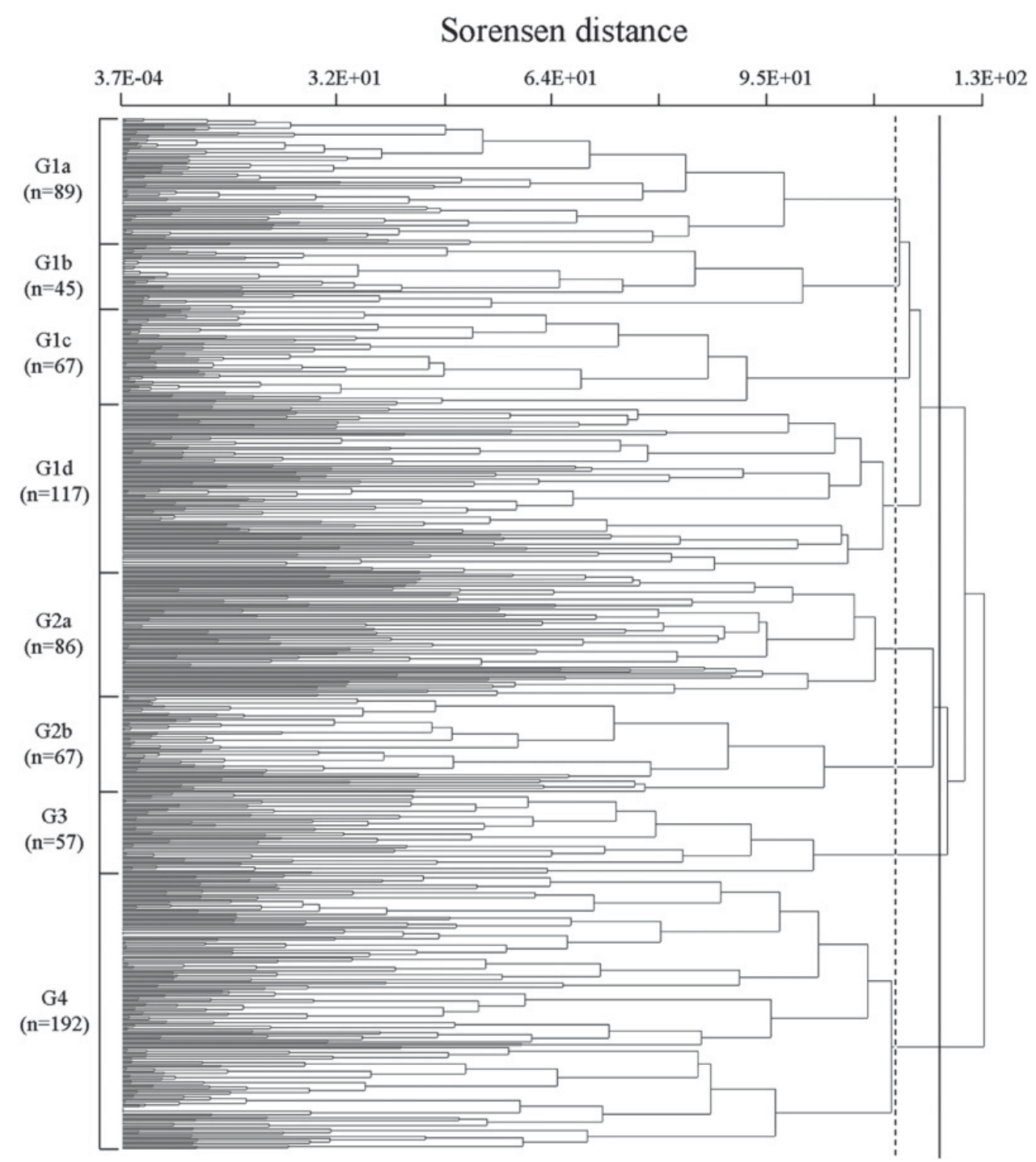

Fig. 2. Dendrogram of diatom-based stream site classification using Sorensen's clustering method. The solid line differentiates the four diatom-based groups and the dashed line differentiates the eight diatom-based groups. See the text for abbreviations of group names.

In particular, sampling sites in Group 1a were in the mountainous tributaries of the HRW and NRW (Fig. 3), and had the highest mean altitude $(221 \mathrm{~m})$ of all groups (Fig. 4). Sites of Group $1 \mathrm{~b}$ had a high proportion of forest land cover $(50 \%)$, and a low proportion of agricultural $(28 \%)$ and urban land use $(20 \%)$. The hydrogeography of Group 1a sites (i.e., mountainous locations) seemed to affect their water chemistry, but the results did not indicate a clear association for all sites of this group, maybe due to their scattered distribution. Geographic location and water chemistry had a clearer relationship in the sites of Group 1b. Group 1b sites were mostly in the eastern mountainous region (Fig. 3), in which there is a high mean altitude $(201 \mathrm{~m})$, significant forest land $(73 \%)$, significant current velocity (mean $63 \mathrm{~m} . \mathrm{s}^{-1}$ ), low nutrient concentrations, and low EC (Fig. 4). Sites of Group 1c were almost all in regions downstream of the South Han River, where human activities, such as agriculture and urban development, were predominant (Fig. 3). In Group 1c, the mean concentrations of $\mathrm{TN}\left(2.9 \mathrm{mg} . \mathrm{L}^{-1}\right)$ and $\mathrm{NO}_{3}-\mathrm{N}$ (2.3 mg. $\mathrm{L}^{-1}$ ) were in the high range (Fig. 4). Sites of Group 1d were dispersed across the country (Fig. 3), had a variety of different land uses, and had nutrient concentrations in the low range. In particular, mean concentrations of TN $\left(0.03 \mathrm{mg} . \mathrm{L}^{-1}\right)$ and $\mathrm{PO}_{4}-\mathrm{P}\left(0.01 \mathrm{mg} . \mathrm{L}^{-1}\right)$ were the lowest among all groups (Fig. 4).

The sites of Groups $2 \mathrm{a}$ and $2 \mathrm{~b}$ were almost exclusively in lowland agricultural and urban areas, and included the downstream Han River and most of the YRW, respectively (Fig. 3). Both groups had relatively low flow and very eutrophic waters. Group $2 b$ had the highest mean nutrient enrichment of all eight groups $(P<0.01)$ (Fig. 4).

The sites of Group 3 were mostly in the SRW (Fig. 3). These sites had very low proportions of urban land use (Fig. 4). The water quality was good (similar to Group 1b), as indicated by the lowest BOD $\left(0.8 \mathrm{mg}^{-\mathrm{L}^{-1}}\right)$ and relatively high nutrient concentrations. Group 3 had the slowest mean current velocity $\left(12 \mathrm{~cm} . \mathrm{s}^{-1}\right)$. 


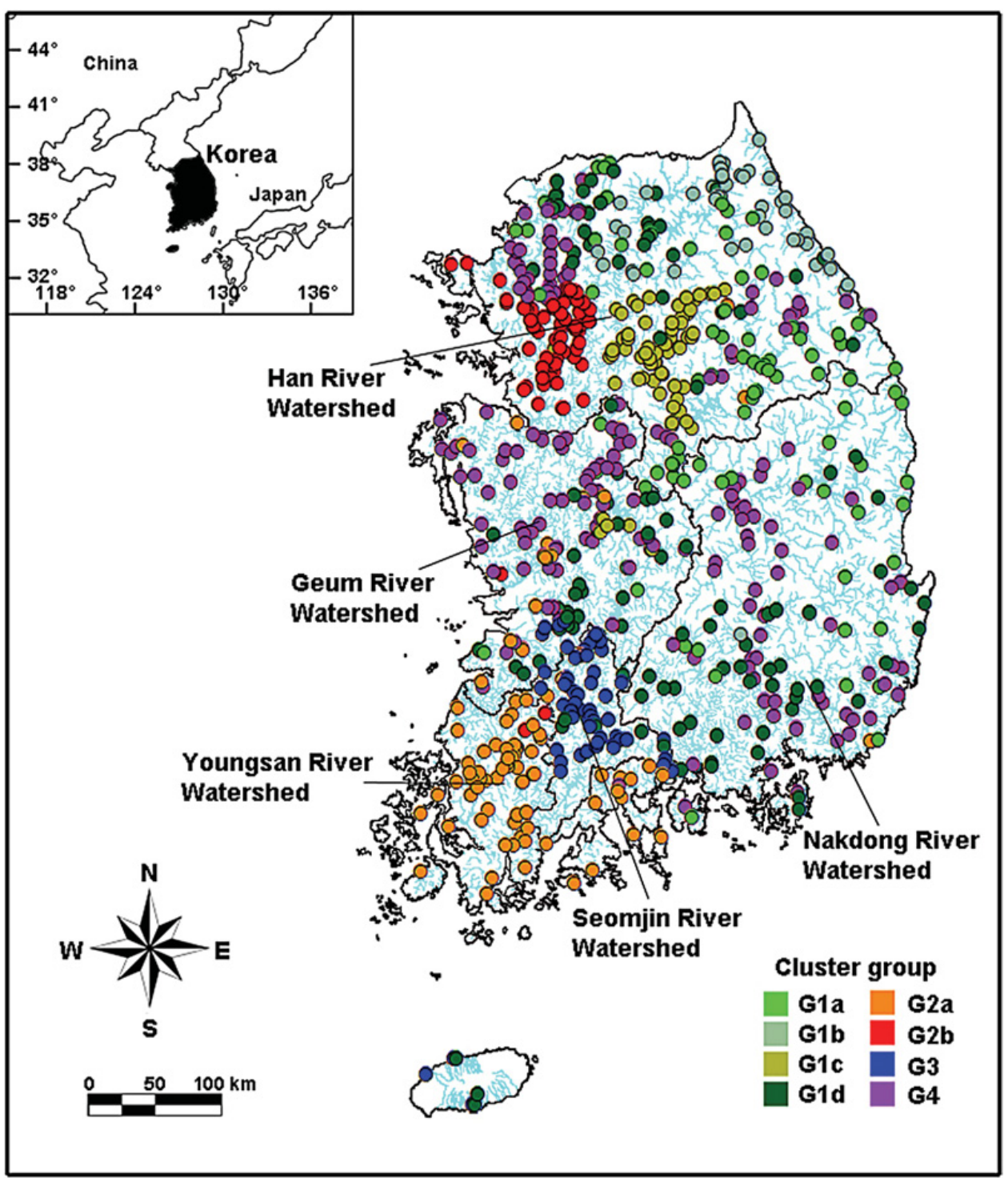

Fig. 3. Geographical position of the eight diatom-based site groups.

The sites of Group 4 had a wide geographic distribution and were mostly present in lowland areas, particularly in the GRW and NRW. This group also included sites of a major tributary (Imjin River) that is located in the northwestern region of the HRW (Fig. 3). Land uses of these sites were variable and water quality was intermediate (Fig. 4).

We used IndVal to identify indicator species in each of the eight groups (Table 3). A total of 81 species were present in more than $5 \%$ of all study sites and different numbers of indicator species were present in the different groups, ranging from 17 species (Group 4) to 4 species (Group 1a). The indicator species with high indicator values $(>50 \%)$ differed among the different groups. The highest indicator value (94\%) was for G. pumilum, which was common in sites of the SRS (Fig. 1) and Group 3 (Table 3). Cymbella tumida (Brébisson) Van Heurck was predominant in the HRW (Fig. 1) and had a high indicator value $(65 \%)$ in Group 1 b (Table 3). N. inconspicua was predominant in sites of the NRW (Fig. 1), and had a high indicator value (86\%) in Group 4. Navicula cryptocephala Kützing was the predominant species in the HRW, particularly in the downstream region and in Group $2 \mathrm{~b}$. Other diatom taxa with indicator values more than $50 \%$ were Aulacoseira granulata (Ehrenberg) Simonsen, Fragilaria construens (Ehrenberg) Grunow, Navicula minima Grunow, A. minutissima, and C. placentula Ehrenberg.

\section{Ordination of diatom assemblages}

Next, sites clustered using Sorenson's method were plotted by CCA in the ordination space in relation to environmental variables (Fig. 5). The eigenvalues of the first CCA axis (0.201) and the second CCA axis (0.094) were both significant $(P<0.01 ; 99$ Monte Carlo permutations test with 99 permutations), and the total 
Table 3. Indicator values $(\%)$ for the most important species $(P<0.05)$ clustered in each group. Monte Carlo simulations (999 permutations) were used to assess the significance of each species as an indicator for each site group. There were 81 species that occurred at more than $5 \%$ of all sites, and these species were used for site classification analysis. Less important species are not shown.

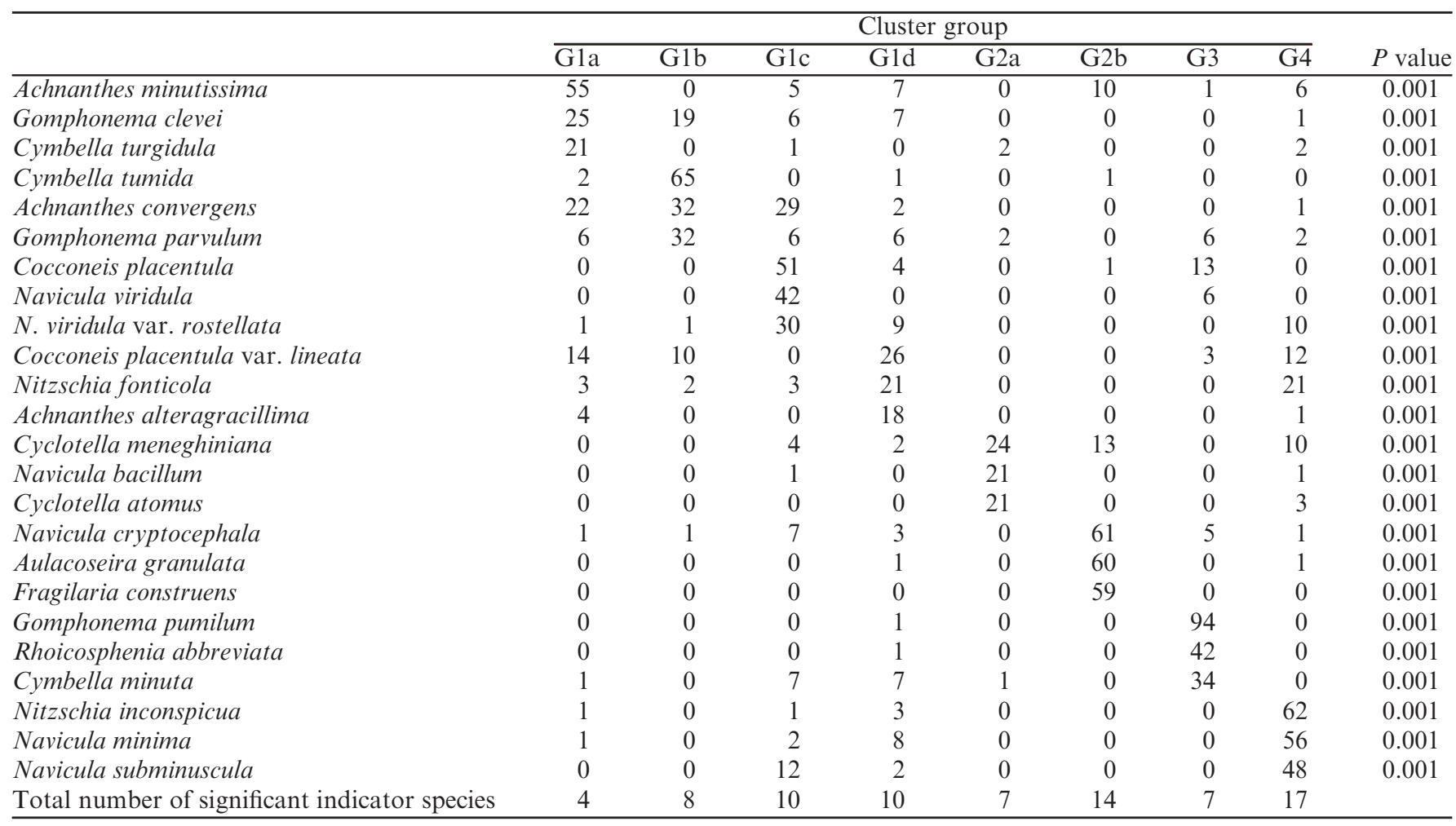
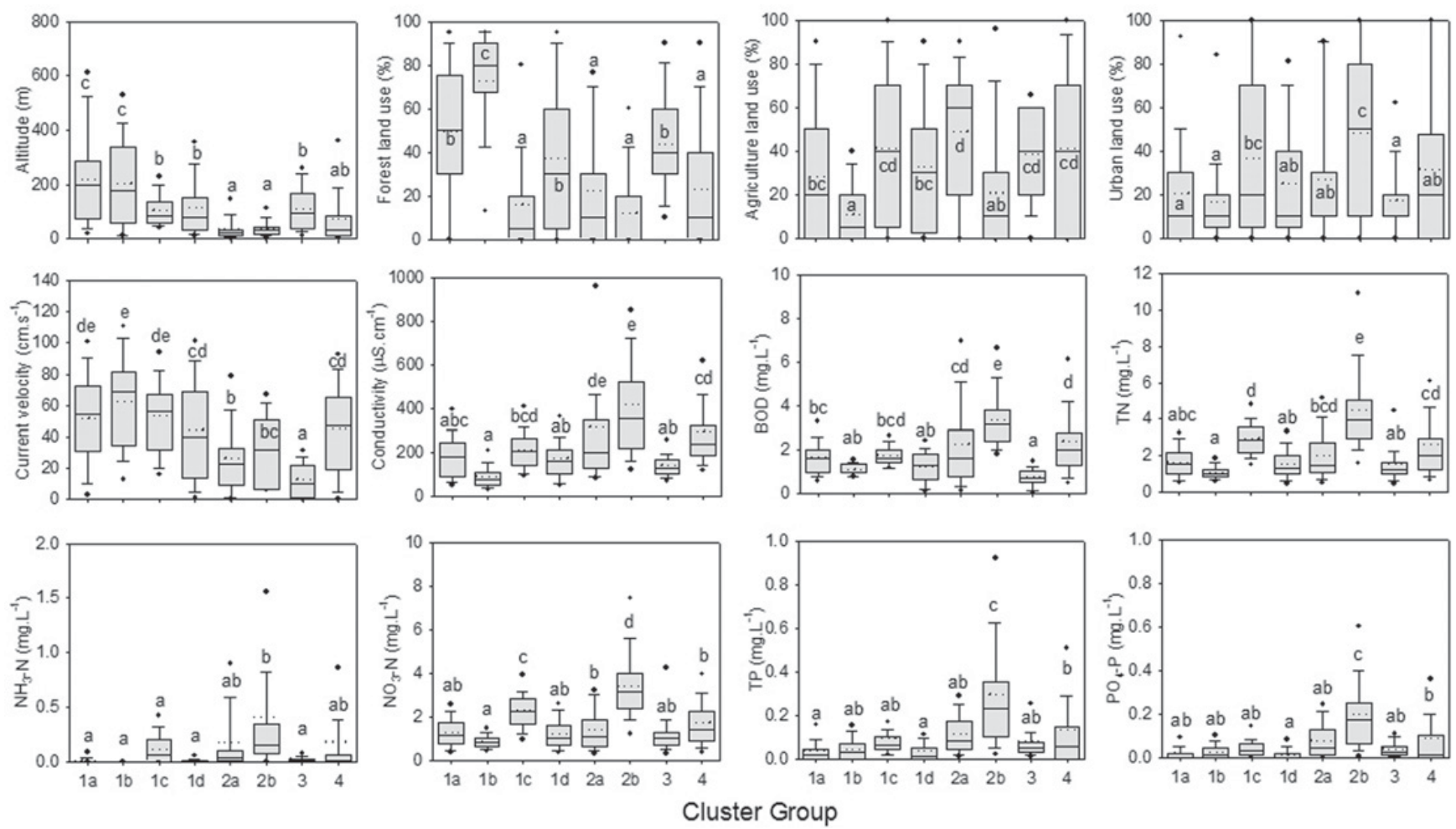

Fig. 4. Boxplots of selected environmental variables of cluster groups. The mean (horizontal dotted line), median (horizontal solid line), range from the 5th to the 95th percentile (dots at the bottom and top of each box), and standard deviation (error bar) are shown in each box. Letters in or on the bars indicate significant difference among cluster groups $(P<0.05)$. 

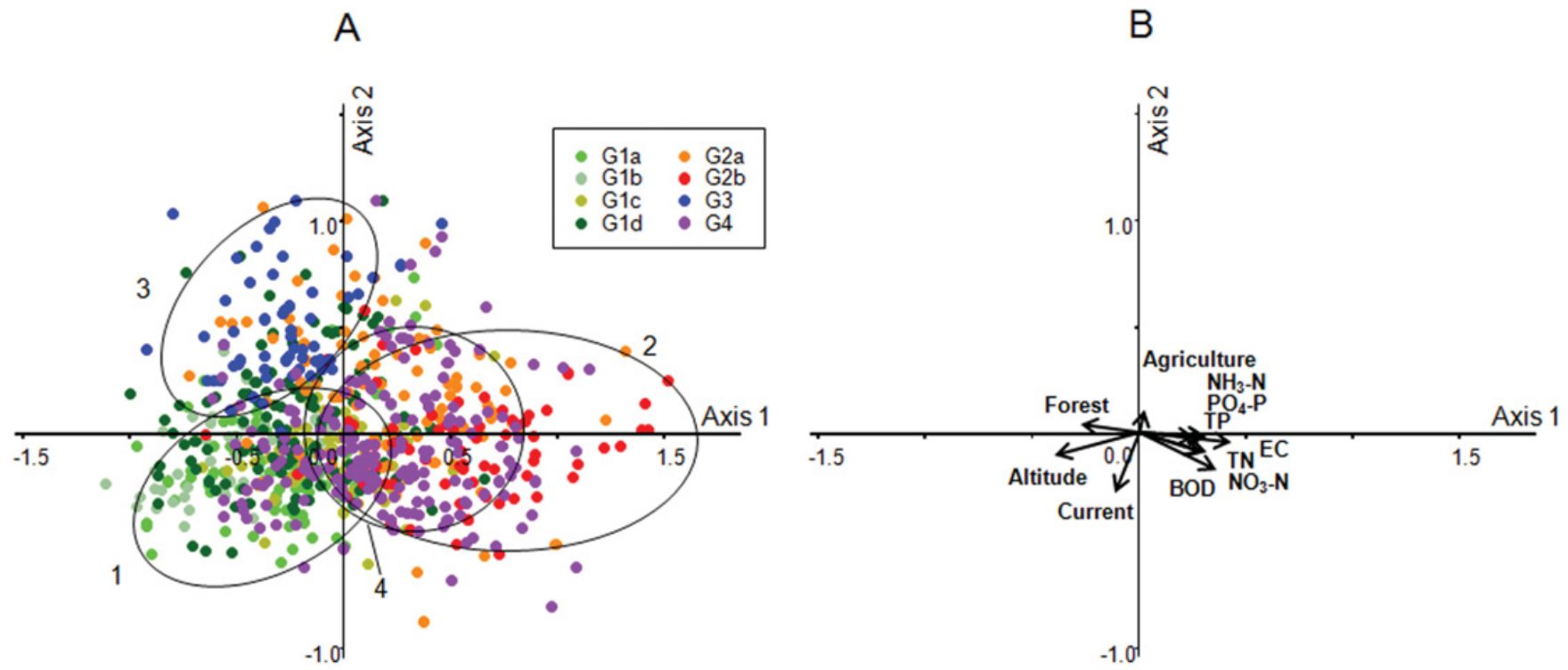

C

\begin{tabular}{lcc}
\hline \multirow{2}{*}{$\begin{array}{l}\text { Environmental } \\
\text { Variables }\end{array}$} & \multicolumn{2}{c}{ Probability } \\
\cline { 2 - 3 } Land cover/use & \multicolumn{2}{c}{ Axis2 } \\
$\quad$ Forest & $-0.555^{* *}$ & -0.046 \\
$\quad$ Agriculture & $0.144^{* *}$ & $0.211^{* *}$ \\
$\quad$ Urban & $0.297^{* *}$ & $-0.113^{* *}$ \\
Altitude & $-0.622^{* *}$ & $-0.277^{* *}$ \\
Current velocity & $-0.260^{* *}$ & $-0.675^{* *}$ \\
EC & $0.616^{* *}$ & $-0.091^{*}$ \\
$\mathrm{BOD}$ & $0.620^{* *}$ & $-0.376^{* *}$ \\
$\mathrm{TN}$ & $0.533^{* *}$ & $-0.120^{* *}$ \\
$\mathrm{TP}$ & $0.506^{* *}$ & -0.004 \\
$\mathrm{NH}$ & $0.357^{* *}$ & -0.033 \\
$\mathrm{NO}_{3}-\mathrm{N}$ & $0.554^{* *}$ & $-0.128^{* *}$ \\
$\mathrm{PO}_{4}-\mathrm{P}$ & $0.529^{* *}$ & -0.036 \\
\hline
\end{tabular}

Fig. 5. (A) Ordination diagram showing the distributions of the four and eight cluster groups (denoted by numbers and corresponding circles). (B) Relative contributions of environmental variables in the CCA space. (C) Correlation coefficients and probabilities of environmental variables and the first two CCA axes $(* P<0.05, * * P<0.01)$.

explained variance in the species data was $6.5 \%$. The diatom-environment correlations for CCA axis-1 (0.758) and CCA axis-2 (0.573) were high, indicating a relatively strong relationship between diatom species and measured environmental variables. All the variables included in this analysis were significantly correlated with axis-1, and among these, altitude $(r=-0.622, P<0.01)$ was the most significant contributor (Fig. 5C); EC, BOD, and forest land cover were also important variables. Analysis of nutrients indicated that $\mathrm{NO}_{3}-\mathrm{N}, \mathrm{TN}$, and $\mathrm{PO}_{4}-\mathrm{P}$ had strong correlations with axis-1. Current velocity $(r=-0.675$, $P<0.01)$ was most significantly correlated with axis-2, followed by BOD and altitude (Fig. 5C).

Overall, clusters of diatom assemblages were not significantly separated in the ordination space (Fig. 5A), indicating that site specificities of many diatom species were not strong at the nationwide scale. This result is also supported by the geographical dispersion of sampling sites across Korea (Fig. 3). In particular, the sites of Group 4 were mostly located in the middle of the ordination space, and there was a large overlap with Groups $2 \mathrm{a}$ and $2 \mathrm{~b}$. Otherwise, the overall site distribution is evident and separation of some site clusters (Groups 1 all together, 2b, and 3 ) is clear. Altitude and nutrient concentrations were most important in separating the clusters of Groups 1 and 3 from Group 2; current velocity was the most important factor for separating the clusters of Group 3 (Figs. 5B and 5C).

The indicator species in each group were analyzed in relation to land cover and use, hydrographical variables, and water quality variables (Table 4). In spite of some variations in the correlation results, many indicator species reflected the overall conditions of their habitats. The most significant indicator species in Group la (A. minutissima) had positive correlations with forest land cover and altitude, and negative correlations with nutrients and EC, indicating its preference for oligotrophic waters. Cymbella turgidula Grunow was similar to A. minutissima, but 


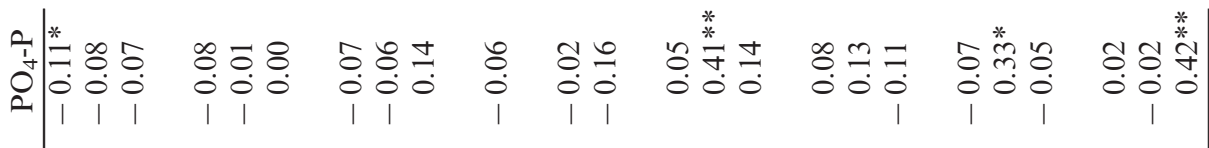

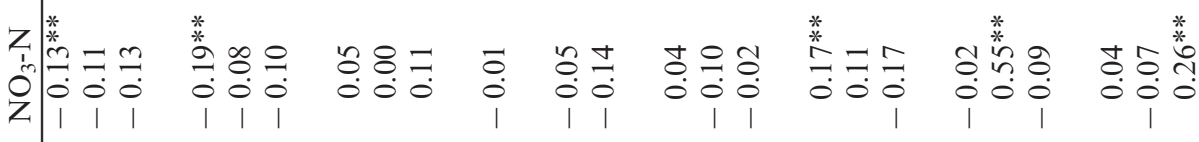

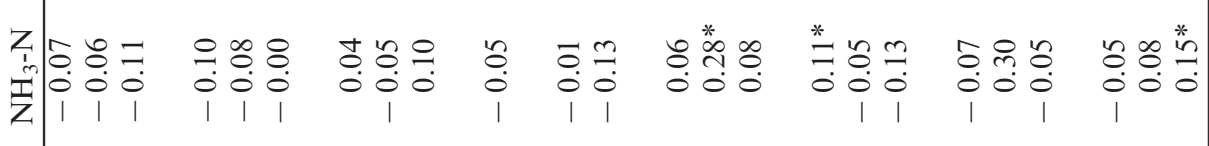

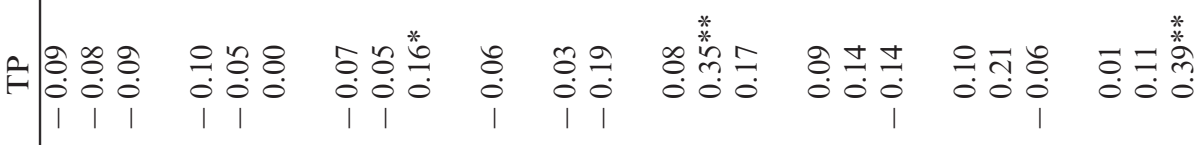

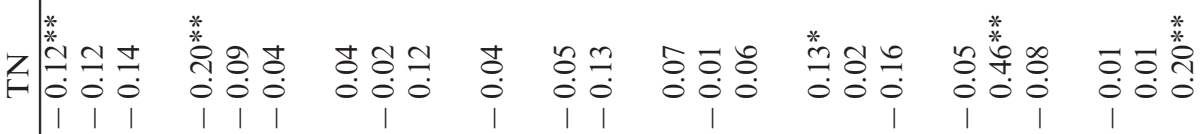

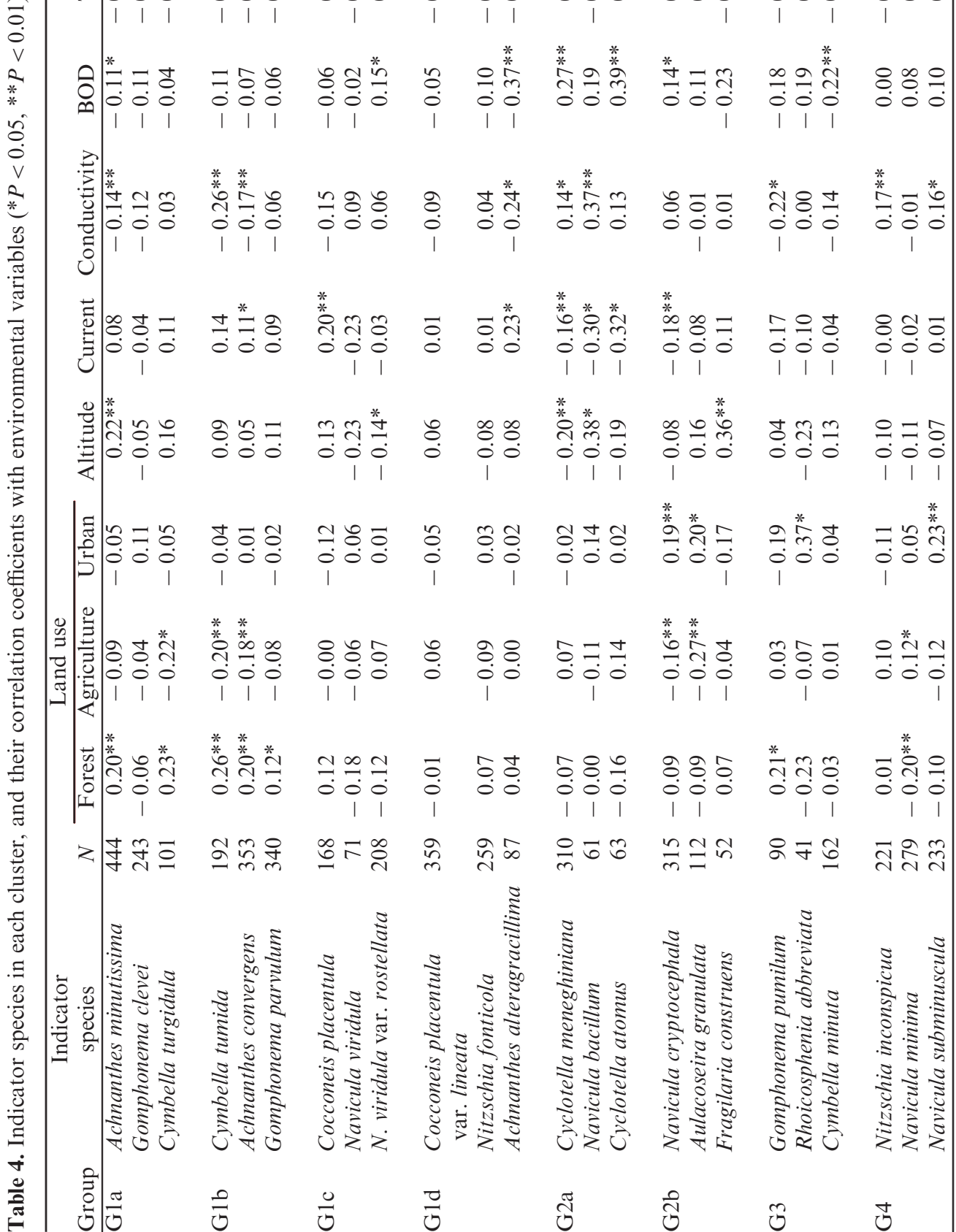


its correlation with nutrients was not significant. All major indicator species (C. tumida, A. convergens, and Gomphonema parvulum Kützing) were in Group 1b and were significantly correlated with a mountainous character and high proportion of forest land cover. None of the indicator species in Groups 1c and 1d had significant correlations to proportion of forest land cover. Overall, almost all of the indicator species in site clusters of Group $1(\mathrm{a}+\mathrm{b}+\mathrm{c}+\mathrm{d})$ had negative correlations with variables of water chemistry, indicating that they preferred oligotrophic waters. This result was supported by the habitat conditions related to the land cover and use patterns near the sampling sites. For example, the correlations between indicator species and nutrients were stronger for Groups 1a and 1b than for Groups 1c and 1d. However, Navicula viridula var. rostellata (Kützing) Cleve (Group 1c), which seemed to prefer eutrophic lowland waters, was a notable exception. The preference for slowly flowing eutrophic waters is striking for indicator species in the site clusters of Group 2a, particularly Navicula bacillum Ehrenberg and N. cryptocephala of Group 2b. Rhoicosphenia abbreviata (C. Agardh) LangeBertalot (Group 3) and Navicula subminuscula Manguin (Group 4) also had strong correlations with nutrient concentrations.

\section{Nationwide distribution of benthic diatoms}

The major benthic diatoms identified as indicator species in each group exhibited large spatial variations at the national scale (Fig. 6). In particular, A. minutissima and $A$. convergens had high abundances almost nationwide (Figs. 6A and 6D), indicating adaptability to a broad range of lotic ecosystems in Korea. Similarly, Gomphonema clevei Fricke and C. tumida had widespread distributions, but their dominance was regional (Figs. 6B and $6 \mathrm{C}$ ). G. clevei dominated in the four major river systems, except for the SRW, and C. tumida was dominant in upstream and headwater sites in mountainous regions of the HRW. C. placentula and $N$. viridula (Kützing) Ehrenberg had regionally clumped but distinct spatial separation; their dominance was concentrated in the middle region of the HRW and SRW (Figs. 6E and 6F). $G$. pumilum and $R$. abbreviata had rather restricted distribution in the SRW (Figs. 6M and 6N). The high density of N. bacillum and Cyclotella meneghiana Kützing was evident in the YRW (Figs. 6I and 6J). However, the occurrence of $C$. meneghiana is peculiar, with dominance mostly in the western region of the country. N. cryptocephala and A. granulata were found particularly in the downstream regions of the HRW (Figs. 6K and 6L), but the distribution of $N$. cryptocephala was much broader, and it covered more regions of the SRW than A. granulata. Several diatoms had a broad occurrence (Figs. 6G, 6H, 6O and 6P). In particular, C. placentula var. lineata and Nitzschia fonticola Grunow largely dominated in the GRW and NRW (Figs. 6G and 6H). N. inconspicua and N. minima had similar spatial patterns (Figs. 6O and 6P); both were scattered in many regions, but were absent in the SRW and northeastern mountainous region of the HRW, where C. tumida was dominant.

\section{Discussion}

\section{Taxonomic composition}

We recorded a total of 531 diatom taxa in this nationwide survey of rivers and streams in Korea. This represents about $73 \%$ of the 724 freshwater diatom taxa (planktonic and benthic species) that have been identified in Korea (Lee, 1988). The number of diatoms in Korea is lower than that reported in the USA, in which 1548 diatom species (including 87 planktonic forms) were recorded in 2735 samples from rivers (Potapova and Charles, 2002). Diatoms in Korean rivers and streams were dominated by species of Achnanthes, Navicula, Nitzschia, Cocconeis, Fragilaria (Synedra included), Cymbella, Gomphonema, and Melosira (Fig. 1, and also see the Appendix). The major diatom species present in Korean rivers and streams have been recorded in rivers throughout the world, including China (Wu et al., 2009), Hong Kong (Dickman et al., 2005), Japan (Watanabe et al., 1986), the USA (Potapova and Charles, 2003), Spain (Leira and Sabater, 2005), Italy (Bona et al., 2007), Germany (Werner and Köhler, 2005), and Finland (Soininen et al., 2004).

In the present study, we found that many diatom taxa occurred in diverse rivers and streams, but that other taxa had more restricted distributions. For example, G. pumilum occurred almost exclusively at sites of the SRW (Fig. 1) and M. varians was very common and had the highest frequency in sites of the YRW, but was not exclusive to this system. In addition, the major species appeared to have different abundances in the five major river watersheds (Fig. 1). Based on our cluster analysis, the most common benthic diatoms differed among the different sites of the five river watersheds, but other taxa occurred in two or more systems.

\section{Relationships of benthic diatom distribution and environmental variables}

A variety of environmental parameters, singly or in combination, directly and/or indirectly affect the species composition and distribution of stream biota (e.g., Giller and Malmqvist, 1998). In a previous study of diatom ecology, Stevenson (1997) organized various multi-scale factors into a hierarchical framework, in which high-level factors (e.g., climate, geology, land use, and physiography) can restrict low-level factors. Low-level, proximate factors including resources (nutrients), stressors (temperature, toxic substances, ionic strength, flow regime), and habitats directly affect diatom distribution. At spatial and temporal scales, the effects of proximate factors can be constrained by high- or intermediate-level factors. 

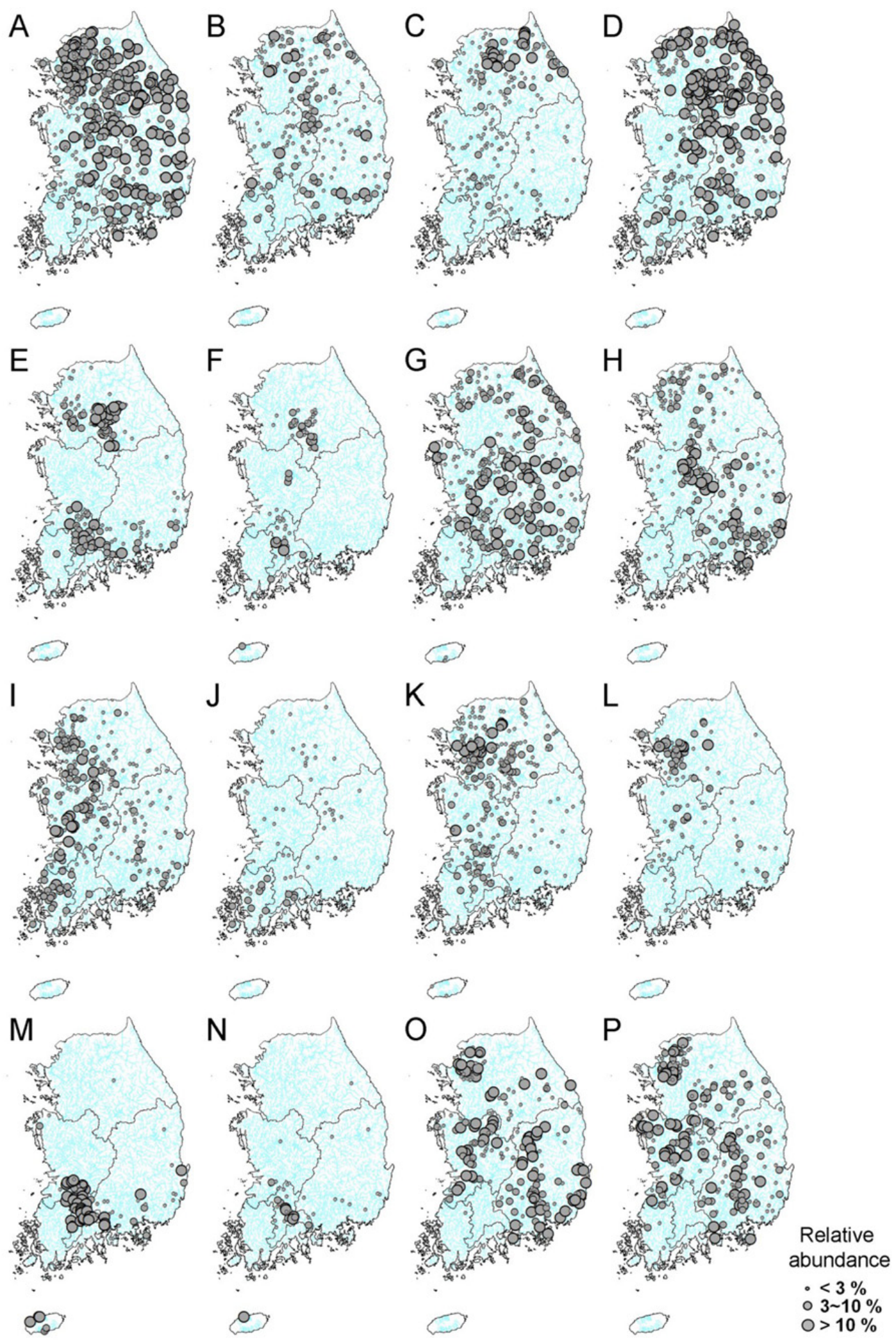

Fig. 6. Spatial distribution of the major diatom indicator species of benthic diatoms in each site cluster. (A) Achnanthes minutissima, (B) Gomphonema clevei, (C) Cymbella tumida, (D) Achnanthes convergens, (E) Cocconeis placentula, (F) Navicula viridula, (G) Cocconeis placentula var. lineata, (H) Nitzschia fonticola, (I) Cyclotella meneghiniana, (J) Navicula bacillum, (K) Navicula cryptocephala, (L) Aulacoseira granulata, (M) Gomphonema pumilum, (N) Rhoicosphenia abbreviata, (O) Nitzschia inconspicua, and (P) Navicula minima. See Table 3 for corresponding cluster groups. 
Thus, the species-specific sensitivity of diatoms to many environmental conditions manifests as great variations of species composition and diatom assemblages in different rivers and streams (Stevenson, 1997; Potapova and Charles, 2002). Previous research has established the effects of various multi-scale factors on diatom community structure and distribution in many rivers and streams (Pan et al., 1999; Leland and Porter, 2000; Potapova and Charles, 2002; Leira and Sabater, 2005; Bona et al., 2007; $\mathrm{Wu}$ et al., 2009). The results of the present nationwide study of diatoms in Korea agree with these previous results.

In the present study, cluster analysis and CCA both showed that various multi-scale factors were important in explaining variations in the structure of benthic diatom assemblages of Korean rivers and streams. Our results indicated that a physiographic variable (altitude), land cover and use patterns, chemical variables (EC, BOD, and nutrients), and a physical variable (current velocity) were important factors in site classification. Our CCA analysis showed that altitude was the most important variable separating diatom site groups along axis-1. There were other important factors related to altitude, including forest land cover and current velocity. Considered together, these factors suggest the involvement of a "downstream gradient" (Potapova and Charles, 2002) in the structuring of diatom assemblages at the national scale in Korea. This gradient may not be due to a single factor (e.g., altitude), because a downstream gradient is likely to be complex and associated with other factors, such as nutrient levels, land use, and water flow. In this study, nutrient enrichment appeared to be strongly associated with this complex downstream gradient, as shown previously (e.g., Leira and Sabater, 2005). The site clusters located on the left side of CCA axis-1 represent upstream characteristics, including high altitude, high proportion of forest in the riparian structure, low EC, low BOD, and low nutrients (N and $\mathrm{P}$ ). Upstream sites of the HRW (Groups 1a and b) and almost all sites in the SRW (Group 3) were clearly separated in the ordination space (Fig. 5). However, the sites of the SRW did not have fast current velocities despite their location at relatively high altitude. This may be due to the structure of channels and river beds in the SRW. Most sites in the SRW are long runs, rather than combinations of riffles and pools, and the former tend to have lower flow velocity. Most of our measurements and sampling were in the runs of river reaches in the SRW, and so our results do not indicate that the flows of sampling sites of the SRW were not as fast as those of other river systems.

Sites located on the right side of axis-1 reflect downstream characteristics, including low altitude, high proportion of urban land use, and very high concentrations of ions, organic matter, and nutrients. Sites clustered in Group 2a were almost exclusively confined to the YSW region, a region that is nutrient rich and has other downstream properties.

Although our results indicate a downstream gradient of diatom composition, further studies are needed to describe the distribution patterns in relation to physiographic characteristics (e.g., ecoregions). Such studies require a greater number of study sites in particular regions. For example, some of our groups (e.g., Groups 1d and 4) had wide geographic distributions across river systems, and the site variation was large in the NRW (Fig. 3). The reason for this pattern is not clear, but the use of more study sites in the NRW would provide a better understanding of such scattered distributions. Although nutrient enrichment is generally higher in downstream regions, our results clearly show that a gradient from unpolluted to polluted rivers is very important in structuring benthic diatom assemblages. In particular, our CCA showed a response of diatom communities to conductivity, BOD, and nutrients. Previous research has identified conductivity as an important factor in determining the geographic variation of diatom community structure in various rivers (Potapova and Charles, 2003; Soininen et al., 2004; Bona et al., 2007). Future studies could provide clearer evidence of the role of conductivity in diatom distribution by considering individual ions in multivariate analyses. An increase in ionic content very often accompanies organic and nutrient enrichment (Leland and Porter, 2000; Potapova and Charles, 2002; Leira and Sabater, 2005).

The present study also indicated the potential importance of flow regimes in shaping the structure of benthic diatom assemblages. Our CCA indicated that current velocity was the most important factor separating groups along axis-2. Flood frequency and water velocity have been reported as significantly affecting species composition and biomass development of periphytic algae in streams (Petersen, 1996; Clausen and Biggs, 1997). However, velocity effects seem to vary with the trophic status of streams, probably due to a negative association between biomass accumulation and detachment (which increases with current velocity) (Petersen and Stevenson, 1990; Biggs and Hickey, 1994). The effect of velocity on benthic diatom community structure is not as clear as it is for filamentous benthic algae. However, as benthic diatoms (e.g., stalked forms) often occur in filamentous algal mats, and as diatom structure varies with substratum type (Leland and Porter, 2000), velocity may also play an important role in benthic diatom community structure.

Our results indicated that both $A$. convergens and $A$. minutissima were the most common diatom species in Korean rivers and streams (Fig. 1). These tightly adherent prostrate species are generally considered to be pioneer species (Barbour et al., 1999; Kwon and Lee, 2007) that typically dominate in streams with Cocconeis spp. and small Navicula spp. after severe scouring events (Leland and Porter, 2000). We believe that the predominance of these taxa in most Korean rivers and streams is related to the monsoon climate pattern of Korea, in which typhoons and consequent severe hydrological scouring events occur regularly during the summer (June-August). The influence of stream geomorphology on diatom distribution is noteworthy, as it affects the physical habitats of diatoms. Pan et al. (2006) showed that dominant diatom assemblages in central valley streams of California (USA) are mainly affected by channel morphology, instream habitat, 
and riparian conditions; however, they showed a weak association of diatom assemblages with water chemistry, indicating that diatoms can also be used as indicators of alterations of the physical habitat. We also expect that grazing pressure may affect stream diatom community composition (Koetsier, 2005; Chessman et al., 2009), because benthic diatoms are the principal food source of many aquatic herbivores, such as insects and snails.

\section{Spatial patterns of diatom distributions: implications for biological water quality assessment}

This study showed that there is a considerable spatial variation in benthic diatom assemblages in Korea. Although part of this variation may result from spatially structured parameters that were not measured or from the relatively small number of rivers investigated in some regions (e.g., the NRW), some diatom taxa indicative of Groups $1 \mathrm{c}$ and 3 (e.g., G. pumilum and C. placentula) had regionally restricted patterns (Fig. 6). This indicates that the distribution of some taxa is better explained by spatial parameters than environmental parameters. Even if there were significant correlations of environmental parameters with indicator diatom taxa of Groups 1c and 3, the overall environmental effect on these groups was relatively small relative to other groups (Table 4). Thus, other parameters, such as spatial factors, may also be involved. An exception is the diatoms in Group 4, which had scattered nationwide distributions and were not clearly distinguishable from other groups (Figs. 3 and 5). However, none of the diatom taxa that played important roles in river benthic diatom communities were limited to one region; variation in their dominance among regions may be related to overriding local parameters (Pan et al., 1999; Soininen et al., 2004).

The spatial variation of river benthic diatom communities is due to complicated multi-scale effects (e.g., Stevenson, 1997), with many interrelated factors (Leland and Porter, 2000; Potapova and Charles, 2002). Higherlevel parameters (e.g., climate, geomorphology, vegetation, and land use), which are basic attributes of ecoregion classification, are likely to operate at the watershed and regional levels, imposing constraints on the local biotic interactions in streams. The ecoregion concept was developed to describe landscape characteristics that influence regional patterns of aquatic and terrestrial resources (Omernik, 1987). Subsequently, many studies have used the ecoregion concept to interpret regional biological phenomena and ecosystem function (Hughes and Larsen, 1988; Roth et al., 1996; Butcher et al., 2003; Simboura et al., 2005; Borja et al., 2007). However, there is often less correspondence between spatial patterns of biological communities and ecoregional classification (Whittier et al., 1988; Pan et al., 1999; Potapova and Charles, 2002), probably because of the greater impact of local geomorphic factors (e.g., habitat alteration and destruction, channel straightening, and river bed modification) and disturbance factors (e.g., pollution), which interact in a complicated manner (Biggs et al., 1990). The spatial distribution of benthic river diatoms that we found in the present study is worthy of further investigations in relation to ecoregion classification. The South Korean landscape is divided into 16 ecoregions (Shin and Lee, 2004). At present, the correspondence between diatom spatial patterns and this ecoregional classification is unclear. However, our initial comparison of these relationships suggests a correlation in some regions, including the HRW, YRW, and SRW, where sites of Groups 1b, 1c, 2a, and 3 are located (data not shown).

Potapova and Charles (2002) have described other potential causes of spatial variation of benthic river diatoms. Although many previous studies have investigated the association of various environmental variables with the spatial variation of diatoms, it is difficult to include all possibly related parameters in one study. Future carefully designed studies of benthic river diatom communities are necessary to better understand the relationships between the spatial distribution of diatoms and the biological assessment of water quality. Given the evidence for spatial patterns in diatom community composition, a biological assessment program that uses benthic diatoms would benefit from a better understanding of diatom geographical distribution. For example, some indicator species that are predominant in particular geographical regions may help to identify space-specific reference sites. However, local instream factors that affect environmental and disturbance conditions are often more important than spatial factors in explaining diatom distribution (e.g., Leland and Porter, 2000; Potapova and Charles, 2002). Thus, a combination of regional discrimination and empirical modeling based on local environmental features might provide the most robust framework for diatom-based assessment of the biological integrity of streams and rivers. This strategy has been applied to other stream biota, including macroinvertebrates and fish. However, the degree of variation among different trophic levels may depend on the specific environmental and habitat conditions to which they respond (Roth et al., 1996; Passy et al., 2004). Thus, bioassessment of running waters should benefit from analysis of multiple taxonomic groups.

\section{Conclusions}

This study was the first large-scale investigation of benthic diatoms in Korea. We sampled 720 sites from the five major river systems and their tributaries and found a large number of benthic diatom taxa. Most species were rare and only $15 \%$ of taxa accounted for more than $5 \%$ of the diatoms at individual sites. Multivariate analysis allowed assessment of the spatial patterns and ecological determinants of benthic diatom assemblages. CCA indicated that site classification using groups of benthic diatom assemblages was not strongly discriminatory, as indicated by low eigenvalues and low total variance in species data. This was probably because of parameters 
that we did not measure, and unresolved problems in taxonomic identification associated with such a large study. However, diatom-environmental factor correlations were high, indicating a strong relationship between diatoms and measured environmental variables. Our results show that multi-scale factors are important in explaining most of the variation in benthic diatom assemblages at the national scale, but that a "downstream gradient" was evident, with significant changes occurring from fast-flowing and mostly oligotrophic rivers in mountainous areas to slow-flowing eutrophic lowland rivers. Our results also suggest that a gradient of water mineral content (indicated by conductivity) can affect diatom community structure. However, because a downstream gradient is largely associated with eutrophication (nutrient enrichment), it was difficult to identify individual effects in each gradient. We suggest that future studies on this topic investigate the contribution of individual ions to the conductivity gradient. The information obtained in the present study on the spatial distribution of benthic diatom indicator species and their significance in relation to environmental variables contributes to development of a larger program for assessment of the biological integrity of lotic ecosystems.

Acknowledgements. This study was financially supported by the Ministry of Environment and the National Institute of Environmental Research (Korea). The authors would like to thank all of the survey members involved in the project for their help in the samplings and analyses. The authors also thank the reviewers for their help in improving the scientific quality of the manuscript.

\section{References}

Anderson E.L., Welch E.B., Jacoby J.M., Schimek G.M. and Horner R.R., 1999. Periphyton removal related to phosphorus and grazer biomass level. Freshwater Biol., 41, 633-651.

APHA, 2001. Standard methods for the examination of water and waste water, American Public Health Association, New York

Barbour M.Y., Gerritsen J., Snyder B.D. and Stribling J.B., 1999. Rapid Bioassessment Protocols for Use in Streams and Wadeable Rivers: Periphyton, Benthic Macroinvertebrates, and Fish, 2nd edn., EPA 841-B-99-002, U.S. Environmental Protection Agency, Office of Water, Washington, DC.

Biggs B.J.F. and Hickey C.W., 1994. Periphyton responses to a hydraulic gradient in a regulated river, New Zealand. Freshwater Biol., 32, 49-59.

Biggs B.J.F. and Smith R.A., 2002. Taxonomic richness of stream benthic algae: effects of flood disturbance and nutrients. Limnol. Oceanogr., 47, 1175-1186.

Biggs B.J.F., Duncan M.J., Jowett I.G., Quinn J.M., Hickey C.W., Davies-Colley R.J. and Close M.E., 1990. Ecological characterization, classification, and modeling of New Zealand rivers: an introduction and synthesis. N. Z. J. Mar. Freshwater Res., 24, 277-304.

Bona F., Falasco E., Fassina S., Griselli B. and Badino G., 2007. Characterization of diatom assemblages in mid-altitude streams of NW Italy. Hydrobiologia, 538, 265-274.

Borja A., Josefson A.B., Miles A., Muxika I., Olsgard F., Philips G., German Rodriguea J. and Rygg B., 2007. An approach to the intercalibration of benthic ecological status assessment in the North Atlantic ecoregion, according to the European Water Framework Directive. Mar. Poll. Bull., $55,42-52$.

Butcher J.T., Stewart P.M. and Simon T.P., 2003. A benthic community index for streams in the Northern lakes and forests ecoregion. Ecol. Indic., 3, 181-193.

Chessman B.C., Westhorpe D.P., Mitrovic S.M. and Hardwick L., 2009. Trophic linkage between periphyton and grazing macroinvertebrates in rivers with different levels of a catchment development. Hydrobiologia, 625, 135-150.

Choi J.K., Lee J.H. and Lee K., 1995. Taxonomic studies on diatoms in Korea. I. Classification system and Koreanization of classification level. Korean J. Pycol., 10, $1-11$ (in Korean).

Clausen B. and Biggs B.J.F., 1997. Relationships between benthic biota and hydrological indices in New Zealand streams. Freshwater Biol., 38, 327-342.

Dickman M.D., Peart M.R. and Yim W.W., 2005. Benthic diatoms as indicators of stream sediment concentration in Hong Kong. Int. Rev. Hydrobiol., 90, 412-421.

Dufrene M. and Legendre P., 1997. Species assemblages and indicator species: the need for flexible asymmetrical approach. Ecol. Monogr., 67, 345-366.

Giller P.S. and Malmqvist B., 1998. The Biology of Streams and Rivers, Oxford University Press, Oxford, UK.

Hughes R.M. and Larsen D.P., 1988. Ecoregions: an approach to surface water protection. J. Water Poll. Cont. Fed., 60, 486-493.

Hwang S.J., Kim N.Y., Won D.H., An G.K., Lee J.K. and Kim C.S., 2006. Biological assessment of water quality by using epilithic diatoms in major river systems, Korea. J. Korean Soc. Wat. Qual., 22, 784-795 (in Korean).

Keister J.E. and Peterson W.T., 2003. Zonal and seasonal variations in zooplankton community structure off the central Oregon coast, 1998-2000. Prog. Oceanogr., 5, 341-361.

Kelly M.G., 2002. Role of benthic diatoms in the implementation of the urban wastewater treatment directive in the River Wear, NE England. J. Appl. Phycol., 14, 9-18.

Kelly M.G. and Whitton B.A., 1995. The trophic diatom index: a new index for monitoring eutrophication in rivers. J. Appl. Phycol., 7, 433-444.

Kelly M.G., Bennion H., Burgess A., Ellis J., Juggins S., Guthrie R., Jamieson J., Adriaenssens V. and Yallop M., 2009. Uncertainty in ecological status assessments of lakes and rivers using diatoms. Hydrobiologia, 633, 5-15.

Kim Y.J., 2007. Changes of epilithic diatom communities according to urbanization influence in the Pocheon and Youngpyeong Streams. Korean J. Limnol., 40, 468-480 (in Korean).

Kociolek J.P. and Spaulding S.A., 2000. Freshwater diatom biogeography. Nova Hedwigia, 71, 223-241.

Koetsier P., 2005. Response of a stream diatom community to top predator manipulation. Aquat. Sci., 67, 517-527. 
Krammer K. and Lange-Bertalot H., 1986. Bacillariophyceae 1. Teil: Naviculaceae. In: Ettl H., Gerloff H., Heying J.H. and Mollenhauer D. (eds.), Süßwasserflora von Mittleuropa, Band 2/1, Gustav Fischer Verlag, Stuttgart/New York, $876 \mathrm{p}$.

Krammer K. and Lange-Bertalot H., 1988. Bacillariophyceae 2. Teil: Bacillariaceae, Epithemiaceae, Surirellaceae. In: Ettl H., Gerloff H., Heying J.H. and Mollenhauer D. (eds.), Süßwasserflora von Mittleuropa, Band 2/2, Gustav Fischer Verlag, Stuttgart/New York, 596 p.

Krammer K. and Lange-Bertalot H. 1991a. Bacillariophyceae 3. Teil: Cenrales, Fragilariaceae, Eunotiaceae. In: Ettl H., Gerloff J., Heying H. and Mollenhauer D. (eds.), Süßwasserflora von Mittleuropa, Band 2/3, Gustav Fischer Verlag, Stuttgart/Jena, 576 p.

Krammer K. and Lange-Bertalot H., 1991b. Bacillariophyceae 4. Teil: Achnanthaceae Kritische Eragänzungen zu Navicula (Lineolatae) und Gomphonema. In: Ettl H., Gerloff J., Heying H. and Mollenhauer D. (eds.), Süßwasserflora von Mittleuropa, Band 2/4, Gustav Fischer Verlag, Stuttgart/ New York, 437 p.

Kwon T.H. and Lee J.H., 2007. Assessment of ecological condition improvement by eco-technological restoration in a small stream. Korean J. Env. Ecol., 21, 442-448 (in Korean).

Lee J.H. and Chung J., 1992. Station variation of epilithic diatoms according to pollution degree from the Kumho River. Korean J. Limnol., 25, 31-41 (in Korean).

Lee K., 1988. A checklist of the freshwater diatoms in Korea. Korean J. Phycol., 3, 29-88 (in Korean).

Leira M. and Sabater S., 2005. Diatom assemblages distribution in catalan rivers, NE Spain, in relation to chemical and physiographical factors. Water Res., 39, 73-82.

Leland H.V. and Porter S.D., 2000. Distribution of benthic algae in the upper Illinois River basin in relation to geology and land use. Freshwater Biol., 44, 279-301.

McCune B. and Grace J.B., 2002. Analysis of Ecological Communities, MjM Software Design, Gleneden Beach, OR.

McCune B. and Mefford M.J., 1999. PC-ORD, Multivariate Analysis of Ecological Data version 4.41 MjM Software, Gleneden Beach, OR.

Mielke E.W., Berry K.J. and Johnson E.S., 1976. Multiresponse permutation procedures for a priori classifications. Commun. Stat. Theory Methods, 5, 1409-1424.

MOE/NIER, 2008. Survey and Evaluation of Aquatic Ecosystem Health in Korea, The Ministry of Environment/ National Institute of Environmental Research, Korea (in Korean).

Omernik J.M., 1987. Ecoregions: a spatial framework for environmental management. Ann. Assoc. Am. Geogr., 77, $118-125$.

Pan Y.D., Stevenson R.J., Hill B.H., Kaufmann P.R. and Herlihy A.T., 1999. Spatial patterns and ecological determinants of benthic algal assemblages in Mid-Atlantic streams, USA. J. Phycol., 35, 460-468.

Pan Y.D., Hill B.H., Husby P., Hall. R.K. and Kaufmann P.R., 2006. Relationships between environmental variables and benthic diatom assemblages in California Central valley stream (USA). Hydrobiologia, 561, 119-130.

Passy S.I., Bode R.W., Carlson D.M. and Novak M.A., 2004. Comparative environmental assessment in the studies of benthic diatoms, macroinvertebrates, and fish communities. Int. Rev. Hydrobiol., 89, 121-138.

Petersen C.G., 1996. Response of benthic algal communities to natural physical disturbance. In: Stevensen R.J., Bothwell M.L. and Lowe R.J. (eds.), Algal Ecology: Freshwater Benthic Ecosystems, Academic Press, New York, 375-402.

Petersen C.G. and Stevenson R.J., 1990. Post-state development of epilithic algal communities in different current environments. Can. J. Bot., 68, 2092-2102.

Petersen W.T. and Keister J.E., 2003. Interannual variability in copepod community composition at a coastal station in the northern California Current: a multivariate approach. Deep Sea Res., 50, 2499-2517.

Potapova M.G. and Charles D.F., 2002. Benthic diatom in USA rivers: distributions along spatial and environmental gradients. J. Biogeogr., 29, 167-187.

Potapova M.G. and Charles D.F., 2003. Distribution of benthic diatoms in U.S. rivers in relation to conductivity and ionic composition. Freshwater Biol., 48, 1311-1328.

Roth N.J., Allan J.D. and Erickson D.L., 1996. Landscape influences on stream biotic integrity assessed at multiple spatial scales. Landscape Ecol., 11, 141-156.

Shin J.H. and Lee D.K., 2004. Strategies for restoration of forest ecosystems degraded by forest fire in Kangwon ecoregion of Korea. Forest Ecol. Manag., 201, 43-56.

Simboura N., Panayotidis P. and Papathanassiou E., 2005. A synthesis of the biological quality elements for the implementation of the European Water Framework Directive in the Mediterraneam ecoregion: The case of Saronikos. Gulf Ecol. Indic., 5, 253-266.

Skvortzow B.W., 1929. Freshwater diatoms from Korea. Philippines J. Sci., 38, 283-291.

Soininen J., Paavola R. and Muotka T., 2004. Benthic diatom communities in boreal streams: community structure in relation to environmental and spatial gradients. Ecography, 27, 330-342.

StatSoft Inc., 2004. STATISTICA (data analysis software system), Version 7, http://www.statsoft.com.

Stevenson R., 1997. Scale-dependent causal frameworks and the consequences of benthic algal heterogeneity. J. North Am. Benthol. Soc., 16, 248-262.

Stevenson R.J., Bothwell M.X. and Lowe R.L. (eds.), 1996. Algal Ecology: Freshwater Benthic Ecosystems, Academic Press, New York, 753 p.

ter Braak C.J.F., 1987. Ordination. In: Jongnam R.H.G., Ter Braak C.J.F. and van Tongeren O.F.R. (eds.), Data Analysis in Community and Landscape Ecology, Pudoc, Wageningen, 91-173.

Watanabe T., 2005. Picture Book and Ecology of the Freshwater Diatoms, Uchida Rokakuho Publishing Co., Tokyo, Japan.

Watanabe T., Asai K. and Houki A., 1986. Numerical estimation of organic pollution of flowing water by using the epilithic diatom assemblage - Diatom assemblage index (DAIpo). Sci. Tot. Environ., 55, 209-218.

Watanabe T., Asai K. and Houki A., 1990. Numerical simulation of organic pollution in flowing waters. Encyclopedia Environ. Control Technol., 4, 251-281.

Weckström J. and Korhola A., 2001. Patterns in the distribution, composition and diversity of diatom assemblages in relation to ecoclimatic factors in Arctic Lapland. J. Biogeogr., 28, $31-45$. 
Werner P. and Köhler J., 2005. Seasonal dynamics of benthic and planktonic algae in a nutrient-rich lowland river (Spree, Germany). Int. Rev. Hydrobiol., 90, 1-20.

Whittier T.R., Hughes R.M. and Larsen D.O., 1988. Correspondence between ecoregions and spatial patterns in stream ecosystems in Oregon. Can. J. Fish. Aquat. Sci., 45, 1264-1278.
Whitton B.A. and Rott E. (eds.), 1996. Use of algae for monitoring rivers. II. In: Proceedings of an International Symposium, Innsbruck, Austria.

Wu N., Tang T., Qu X. and Cai Q., 2009. Spatial distribution of benthic algae in the Gangqu River, Shangrila, China. Aquat. Ecol., 43, 37-49.

Appendix 1. Diatom taxa $(n=126)$ that occurred in the greatest density at more than one site among the five major river watersheds in Korea. Asterisks indicate abundance. *Presence of taxa regardless of their abundance. ${ }^{*}$ Dominant taxa ( $>10 \%$ in overall abundance).

\begin{tabular}{|c|c|c|c|c|c|}
\hline Diatom taxa & $\begin{array}{l}\text { Han } \\
\text { River }\end{array}$ & $\begin{array}{l}\text { Nakdong } \\
\text { River }\end{array}$ & $\begin{array}{l}\text { Geum } \\
\text { River }\end{array}$ & $\begin{array}{c}\text { Youngsan } \\
\text { River }\end{array}$ & $\begin{array}{r}\text { Seomjin } \\
\text { River }\end{array}$ \\
\hline
\end{tabular}

Suborder Coscinodiscineae

Family Thalassiosiraceae

Aulacoseira alpigena (Grunow) Krammer

Aulacoseira granulata (Ehrenberg) Simonsen

Cyclotella atomus Hustedt

Cyclotella comta (Ehrenberg) Kützing

Cyclotella meneghiniana Kützing

Cyclotella stelligera (Cleve \& Grunow) Van Heurck

Cyclotella spp.

Stephanodiscus alpinus Hustedt

Family Melosiraceae

Melosira varians $\mathrm{C}$. Agardh

Stephanopyxis spp.

Family Hemidiscaceae

Actinocyclus normanii (W. Gregory) Hustedt

Order Pennales

Suborder Araphidineae

Family Fragilariaceae

Diatoma hiemale var. quadratum (Kützing) R. Ross

Diatoma vulgaris Bory

Diatoma spp.

Fragilaria capitata (Ehrenberg) Lange-Bertalot

Fragilaria capucina Desmazières

Fragilaria capucina var. capitellata (Grunow) Lange-Bertalot

Fragilaria capucina var. mesolepta (Rabenhorst) Rabenhorst

Fragilaria construens (Ehrenberg) Grunow

$F$. construens f. binodis (Ehrenberg) Hustedt

F. construens f. venter (Ehrenberg) Hustedt

Fragilaria crotonensis Kitton

Fragilaria elliptica Schumann

Fragilaria vaucheriae (Kützing) J. B. Petersen

Fragilaria vaucheriae var. capitellata (Grunow) R. M. Patrick

Fragilaria spp.

Hannaea arcus (Ehrenberg) R. M. Patrick

Synedra acus Kützing

Synedra fasciculata (Kützing) Grunow

Synedra inaequalis H. Kobayasi

Synedra ulna (Nitzsch) Ehrenberg

Synedra ulna var. contracta Østrup

Suborder Raphidineae

Family Achnanthaceae

Achnanthes alteragracillima Lange-Bertalot

Achnanthes amoena Hustedt

Achnanthes biasolettiana (Kützng) Grunow

Achnanthes bioretii Germain

Achnanthes brevipes C. Agardh

Achnanthes catenata Bily \& Marvan

Achnanthes conspicua A. Mayer

Achnanthes convergens H. Kobayasi

$\begin{array}{ll}* & \\ * * & * \\ * & * * \\ * * & \\ * * & * \\ * & * \\ * * & \\ * * & * \\ & \\ * *\end{array}$

$\begin{array}{lll}* * & * & \\ * & * & \\ * * & * * & \\ * & * & \\ * * & * * & * \\ * * & * * & \\ & * * & \\ * & & * * \\ * & * * & * *\end{array}$

\begin{tabular}{|c|c|c|c|c|}
\hline$* *$ & & & $* *$ & \\
\hline$* *$ & * & $*$ & $*$ & \\
\hline \multirow[t]{2}{*}{$* *$} & & & $*$ & \\
\hline & & & $* *$ & \\
\hline$* *$ & * & * & $*$ & $* *$ \\
\hline$*$ & & $*$ & $* *$ & \\
\hline$*$ & $*$ & $*$ & $*$ & $* *$ \\
\hline$* *$ & & $*$ & $*$ & \\
\hline$*$ & $*$ & $* *$ & $*$ & $*$ \\
\hline$* *$ & $* *$ & $*$ & $*$ & $* *$ \\
\hline$* *$ & * & $*$ & $*$ & \\
\hline$*$ & $* *$ & $* *$ & & \\
\hline \multirow[t]{3}{*}{$* *$} & & $*$ & $*$ & \\
\hline & & * & $* *$ & \\
\hline & & $*$ & & $* *$ \\
\hline$* *$ & & & $*$ & \\
\hline$* *$ & $*$ & $* *$ & $*$ & $*$ \\
\hline$*$ & $* *$ & $*$ & $*$ & \\
\hline$* *$ & $*$ & $*$ & $*$ & \\
\hline \multirow[t]{2}{*}{$*$} & $* *$ & $* *$ & $* *$ & $*$ \\
\hline & & $*$ & $* *$ & \\
\hline$* *$ & & $* *$ & $*$ & \\
\hline$* *$ & $*$ & & & \\
\hline$* *$ & $* *$ & * & $*$ & \\
\hline \multirow{3}{*}{ ** } & & & & \\
\hline & & $* *$ & & \\
\hline & & & $* *$ & \\
\hline ** & $* *$ & $* *$ & $* *$ & $*$ \\
\hline
\end{tabular}


Appendix 1. Continued.

\begin{tabular}{|c|c|c|c|c|c|}
\hline Diatom taxa & $\begin{array}{l}\text { Han } \\
\text { River }\end{array}$ & $\begin{array}{l}\text { Nakdong } \\
\text { River }\end{array}$ & $\begin{array}{l}\text { Geum } \\
\text { River }\end{array}$ & $\begin{array}{l}\text { Youngsan } \\
\text { River }\end{array}$ & $\begin{array}{r}\text { Seomjin } \\
\text { River }\end{array}$ \\
\hline Achnanthes delicatula ssp. engelbrechtii (Choln.) Lange-Bertalot & & & & $* *$ & \\
\hline Achnanthes exigua Grunow & * & * & $* *$ & $* *$ & $*$ \\
\hline Achnanthes impexa Lange-Bertalot & & * & ** & & \\
\hline Achnanthes laevis Øestrup & $* *$ & & & $*$ & \\
\hline Achnanthes lanceolata (Brébisson) Grunow & $* *$ & ** & * & $*$ & $*$ \\
\hline Achnanthes lanceolata ssp. dubia (Grunow) Lange-Bertalot & $* *$ & * & & $*$ & \\
\hline Achnanthes microcephala (Kützing) Grunow & & & & $* *$ & \\
\hline Achnanthes minutissima Kützing & $* *$ & ** & ** & $*$ & $* *$ \\
\hline Achnanthes minutissima var. saprophila Kobayasi \& Mayama & & * & * & $* *$ & \\
\hline Achnanthes minutissima var. scotica Kützing & & & & $* *$ & \\
\hline Achnanthes subhudsonis Hustedt & $*$ & * & $*$ & $* *$ & \\
\hline Achnanthes spp. & * & * & $*$ & $*$ & ** \\
\hline Cocconeis placentula Ehrenberg & $* *$ & * & & $*$ & $* *$ \\
\hline Cocconeis placentula var. euglypta (Ehrenberg) Grunow & $* *$ & $* *$ & & $* *$ & $*$ \\
\hline Cocconeis placentula var. lineata (Ehrenberg) Van Heurck & $* *$ & $* *$ & $* *$ & $*$ & $* *$ \\
\hline $\begin{array}{l}\text { Cocconeis spp. } \\
\text { Family Naviculaceae }\end{array}$ & * & & & $*$ & $* *$ \\
\hline Amphora ovalis (Kützing) Kützing & ** & & * & * & \\
\hline Amphora spp. & $* *$ & & $*$ & $*$ & $*$ \\
\hline Caloneis bacillum (Grunow) Cleve & $* *$ & $*$ & * & $*$ & \\
\hline Cymbella affinis Kützing & $* *$ & * & ** & $*$ & ** \\
\hline Cymbella amphicephala Nägeli & * & & & $* *$ & \\
\hline Cymbella cinuata $\mathrm{W}$. Gregory & $* *$ & $* *$ & * & & \\
\hline Cymbella cistula (Hemprich \& Ehrenberg) O. Kirchner & $* *$ & & & $*$ & $*$ \\
\hline Cymbella lacustris (C. Agardh) Cleve & $* *$ & * & * & $*$ & \\
\hline Cymbella minuta Hilse ex Rabenhorst & * & * & $* *$ & $*$ & $*$ \\
\hline Cymbella silesiaca Bleisch & $* *$ & * & $* *$ & $*$ & $*$ \\
\hline Cymbella tumida (Brébisson) Van Heurck & $* *$ & * & * & $*$ & $*$ \\
\hline Cymbella turgidula Grunow & $* *$ & * & * & $*$ & $*$ \\
\hline Cymbella spp. & & & * & $* *$ & \\
\hline Gomphonema lagenula Kützing & $* *$ & & & & \\
\hline Gomphonema angustum C. Agardh & $* *$ & * & * & $*$ & $*$ \\
\hline Gomphonema clavatum Ehrenberg & $* *$ & & * & $*$ & $*$ \\
\hline Gomphonema clevei Fricke & $* *$ & $* *$ & $* *$ & $*$ & \\
\hline Gomphonema dichotomum Kützing & & & & $*$ & $* *$ \\
\hline Gomphonema herculeana Ehrenberg & & & * & $* *$ & \\
\hline Gomphonema insigne Gregory & * & & & $* *$ & \\
\hline Gomphonema minutum (C. Agardh) C. Agardh & $* *$ & $* *$ & * & & \\
\hline Gomphonema olivaceum (Hornemann) Brébisson & $* *$ & & & $* *$ & \\
\hline Gomphonema parvulum Kützing & ** & * & $* *$ & $* *$ & ** \\
\hline Gomphonema pumilum (Grunow) Reichardt \& Lange-Bertalot & * & * & * & $* *$ & $* *$ \\
\hline Gomphonema truncatum Ehrenberg & ** & $*$ & * & $*$ & $*$ \\
\hline Navicula cincta (Ehrenberg) Kützing & $*$ & * & * & $*$ & $* *$ \\
\hline Navicula contenta Grunow & & & $* *$ & $*$ & \\
\hline Navicula cryptocephala Kützing & $* *$ & * & ** & $*$ & * \\
\hline Navicula cryptotenella Lange-Bertalot & ** & $* *$ & * & $*$ & $*$ \\
\hline Navicula elginensis var. cuneata (M. Moller ex. Foged) Lange-Bertalot & & & & $* *$ & \\
\hline Navicula goeppertiana (Bleisch) H. L. Smith & $* *$ & $* *$ & $* *$ & $*$ & $* *$ \\
\hline Navicula minima Grunow & $* *$ & $* *$ & $* *$ & $* *$ & \\
\hline Navicula mutica var. ventricosa (Kützing) Cleve \& Grunow & & * & * & $* *$ & \\
\hline Navicula neoventricosa Hustedt & & $* *$ & & $*$ & \\
\hline Navicula nipponica (Skvortzow) Lange-Bertalot & * & & & $* *$ & $*$ \\
\hline Navicula nivalis Ehrenberg & * & & $* *$ & $* *$ & \\
\hline Navicula notha Wallace & * & * & * & $* *$ & $*$ \\
\hline Navicula novasiberica Lange-Bertalot & & & & $* *$ & \\
\hline Navicula perminuta Grunow & * & * & * & $* *$ & \\
\hline Navicula pupula Kützing & * & * & $* *$ & $* *$ & $*$ \\
\hline Navicula recens (Lange-Bertalot) Lange-Bertalot & & $* *$ & & & \\
\hline Navicula saprophila Lange-Bertalot \& Bonik & $* *$ & & $*$ & $* *$ & \\
\hline Navicula schroeteri var. symmetrica (Patrick) Lange-Bertalot & & & $* *$ & & \\
\hline Navicula seminulum Grunow & $* *$ & $* *$ & * & $*$ & $*$ \\
\hline Navicula subminuscula Manguin & $* *$ & $* *$ & $* *$ & $*$ & $*$ \\
\hline
\end{tabular}


Appendix 1. Continued.

\begin{tabular}{|c|c|c|c|c|c|}
\hline Diatom taxa & $\begin{array}{l}\text { Han } \\
\text { River }\end{array}$ & $\begin{array}{l}\text { Nakdong } \\
\text { River }\end{array}$ & $\begin{array}{l}\text { Geum } \\
\text { River }\end{array}$ & $\begin{array}{l}\text { Youngsan } \\
\text { River }\end{array}$ & $\begin{array}{r}\text { Seomjin } \\
\text { River }\end{array}$ \\
\hline Navicula subtilissima Cleve & & $*$ & $*$ & $* *$ & \\
\hline Navicula tenelloides Hustedt & & & & $* *$ & \\
\hline Navicula viridula (Kützing) Ehrenberg & * & & * & * & $* *$ \\
\hline Navicula spp. & $*$ & $*$ & $* *$ & $* *$ & $* *$ \\
\hline Neidium dubium (Ehrenberg) Cleve & $* *$ & & & & \\
\hline Pinnularia divergens $\mathrm{W}$. Smith & $* *$ & & & & \\
\hline Pinnularia gibba Ehrenberg & ** & $*$ & * & $*$ & $*$ \\
\hline Rhoicosphenia abbreviate (C. Agardh) Lange-Bertalot & $*$ & * & * & $* *$ & $* *$ \\
\hline $\begin{array}{l}\text { Stauroneis anceps Ehrenberg } \\
\text { Family Epithemiaceae }\end{array}$ & $* *$ & & & * & $*$ \\
\hline $\begin{array}{l}\text { Epithemia adnata (Kützing) Brébisson } \\
\text { Family Bacillariaceae }\end{array}$ & * & & & & $* *$ \\
\hline Denticula tenuis Kützing & $* *$ & & & & \\
\hline Nitzschia acicularis (Kützing) W. Smith & * & * & ** & & \\
\hline Nitzschia amphibia Grunow & $* *$ & * & $* *$ & $* *$ & $*$ \\
\hline Nitzschia capitellata Hustedt & ** & * & & $*$ & \\
\hline Nitzschia diversa Hustedt & & & $* *$ & $*$ & \\
\hline Nitzschia filiformis (W. Smith) Van Heurck & $*$ & $*$ & $* *$ & $*$ & \\
\hline Nitzschia fonticola (Grunow) Grunow & $*$ & $* *$ & ** & $* *$ & \\
\hline Nitzschia fossilis Grunow & $* *$ & & & & \\
\hline Nitzschia frustulum (Kützing) Grunow & $* *$ & $*$ & $*$ & $*$ & \\
\hline Nitzschia gracilis Hantzsch & * & $* *$ & $*$ & $* *$ & $* *$ \\
\hline Nitzschia inconspicua Grunow & ** & ** & ** & $* *$ & \\
\hline Nitzschia intermedia Hantzsch ex Cleve \& Grunow & $*$ & $*$ & $*$ & $* *$ & \\
\hline Nitzschia palea (Kützing) W. Smith & $* *$ & $* *$ & ** & $* *$ & $* *$ \\
\hline $\begin{array}{l}\text { Nitzschia spp. } \\
\text { Family Surirellaceae }\end{array}$ & $*$ & $*$ & $* *$ & $*$ & $*$ \\
\hline Surirella minuta Kützing & * & * & $* *$ & $*$ & \\
\hline
\end{tabular}

